\title{
Forest Vocation Lands
}

and Forest Policy: When Simpler is Better

José Rente Nascimento

Rural Development Unit

Sustainable Development Department

Inter-American Development Bank 
Electronic copy of this paper is available at: http://ssrn.com/abstract=977966 


\section{Forest Vocation Lands and Forest Policy: When Simpler is Better}

José Rente Nascimento

Washington, D.C.

December 2005 - No. RUR-05-03 
The Rural Development Unit of the Sustainable Development Department of the Inter-American Development Bank (IDB) has undertaken this study and is grateful to Environmental and Natural Resources Division of the Regional Department II for the time spent by the author in the research while working for this Division. The author would like to acknowledge Cesar Falconi, Robert Kaplan, and Kari Keipi (from the Bank in Washington, D.C.); Peter Pfaumann (Secondee from GTZ at the IDB), Sebastião Kengen (consultant) and Ivan Tomaselli (Professor at the Federal University of Paraná, Brazil and Development Director of STCP Engenharia de Projetos Ltda.), who provided comments and insights to the paper. In addition, Maria Eugenia Kyburz provided valuable editorial assistance.

José Rente Nascimento is Senior Natural Resources Specialist in the Rural Development Unit of IDB's Sustainable Development Department.

The opinions expressed herein are those of the author and do not necessarily reflect the policies or official position of the Inter-American Development Bank or any other organizations mentioned. All errors and omissions are the sole responsibility of the author.

Reference: Nascimento, José Rente (2005). Forest Vocation Lands and Forest Policy: When Simpler is Better. RUR-05-03. Washington, D.C.: Inter-American Development Bank.

December 2005

This publication (Reference No RUR-05-03) can be obtained from:

Rural Development Unit

Mail Stop W-0500

Inter-American Development Bank

1300 New York Avenue, N.W.

Washington, D.C. 20577

E-mail:rural@iadb.org

Fax: 202-312-4025

Website: http://www.iadb.org/sds/ 


\section{Contents}

Acronyms

List of Boxes $\quad \mathrm{V}$

List of Figures $\quad \mathrm{V}$

List of Tables $\quad \mathrm{V}$

I. Executive Summary and Introduction 1

II. Forest Based Externalities

$\begin{array}{ll}\text { Soil loss related externalities and forests } & 6\end{array}$

Biodiversity preservation externalities and forests $\quad 8$

$\begin{array}{ll}\text { Carbon sequestration and stock and forests } & 11\end{array}$

Basic Features $\quad 12$

III. Land Use Planning $\quad 15$

$\begin{array}{ll}\text { Land cover and land use } & 15\end{array}$

$\begin{array}{ll}\text { Soil and land classifications } & 16\end{array}$

$\begin{array}{ll}\text { Soil and land classifications, and the price system } & 20\end{array}$

$\begin{array}{ll}\text { Forest vocation lands } & 21\end{array}$

IV. Land Rent and Forest Vocation Land 25

Land rent and the choice of land use $\quad 25$

Social desirability of land use, cover, and vocation scenarios 28

$\begin{array}{ll}\text { Good and bad deforestation } & 29\end{array}$

$\begin{array}{ll}\text { Relaxing some assumptions } & 30\end{array}$

$\begin{array}{ll}\text { Land rent and biodiversity preservation } & 31\end{array}$

V. Forest Policy Based on Forest Vocation Land 33

The framework 33

Simpler and less costly $\quad 34$

Conditions for successful implementation $\quad 34$

$\begin{array}{ll}\text { Operational aspects } & 36\end{array}$

Other forest implications $\quad 39$

V. Conclusions 45

$\begin{array}{lr}\text { Bibliography } & 49\end{array}$

Annexes $\quad 53$ 


\section{Acronyms}

$\begin{array}{ll}\text { AEZ } & \text { Agro-Ecological Zoning } \\ \text { AVL } & \text { Agriculture Vocation Land (s) } \\ \text { CIFOR } & \text { Center for International Forestry Research } \\ \text { EEZ } & \text { Economic-Ecological Zoning } \\ \text { FAO } & \text { Food and Agriculture Organizations of the United Nations } \\ \text { FVL } & \text { Forest Vocation Land (s) } \\ \text { GLCC } & \text { Global Land Cover Characteristics Database } \\ \text { GTZ } & \text { German Technical Cooperation Agency } \\ \text { IAIF } & \text { Forest Investment Attractiveness Index } \\ \text { IDB } & \text { Inter-American Development Bank } \\ \text { ITTO } & \text { International Timber Trade Organization } \\ \text { IUCN } & \text { The World Conservation Union } \\ \text { LAC } & \text { Latin America and the Caribbean } \\ \text { MS } & \text { Moderately suitable } \\ \text { NFM } & \text { Natural forest management } \\ \text { nFVL } & \text { Non-Forest Vocation Land } \\ \text { NRSC } & \text { Natural Resources Conservation Service } \\ \text { OECD } & \text { Organization for Economic Co-operation and Development } \\ \text { PPP } & \text { Polluter Pay Principle } \\ \text { S } & \text { Suitable } \\ \text { S\&WRE } & \text { Soil and Water Related Externalities } \\ \text { UNESCO } & \text { United Nations Educational, Scientific and Cultural Organization } \\ \text { USDA } & \text { United States Department of Agriculture } \\ \text { VS } & \text { Very suitable }\end{array}$




\section{List of Annexes}

Annex 1

Annex 2

Annex 3

Annex 4

Annex 5

Box 1

Box 2

Box 3

Box 4

Box 5

Box 6

Box 7

Box 8

Box 9

Box 10

Box 11

Figure 1

Figure 2

Figure 3

Figure 4

Figure 5

Figure 6

Figure 7

Figure 8

Figure 9

Basic concepts and classifications related to land.

Forest vocation land estimation for selected Latin America and the Caribbean countries (1,000 ha).

Steeplands in selected Latin American and Caribbean countries.

Examples of the use of forest vocation land concept in forest laws of selected LA

countries.

Glossary.

\section{List of Boxes}

Basic definitions related to biodiversity.

When does an area have a forest cover?

USDA Principal Land Capability Classes.

Forest policy relevant consequences from agriculture land capability classification.

Forest Vocation Land defined.

Polluter Pay Principle defined.

Land rent defined.

Opportunity cost defined.

Forest policy directive.

The importance of illegality for forestry.

Basic results of the study.

\section{List of Figures}

Causal diagram showing the linkages among an area covered with natural forests and welfare.

Descriptive model of factors affecting the erosion rate, as proposed by the Universal Soil Erosion Equation.

Genetic resources and their relationships to specimens, species, and ecosystems.

Some factors affecting forest related carbon stocks, and sequestration and emission rates.

Land rent for agriculture and forest uses for different land quality levels.

Social land rent of genetic resources preservation use must be greater than all other land use costs.

Monitoring locates FVL with erosion risk.

Land cover change types and acceptable land covers.

FVL based forest policy enforcement decision tree.

\section{List of Tables}

Table 1

Table 2

Table 3

Table 4

Table 5
Basic features of forest related externalities.

Sustainable land uses per land capability class.

Potentially cultivatable lands covered with forest ecosystem selected LAC countries. Land use, cover, and vocation and the socially desirability of possible scenarios.

Good or bad deforestation depends on land vocation, and on the land use given to the site afterwards and its respective rent. 



\section{Executive Summary and Introduction}

\section{Forest vocation lands and forest policy: when simpler is better}

Forest policy concerns itself with society's welfare. It is recognized that forests and forest vocation lands make major contributions to the welfare of society by providing goods and services to satisfy its needs or desires. Through private goods and services or externalities, they may affect not only the welfare of the local populations where they are located, but of those in far away regions and countries. In the process of providing such goods and services, the forest sector creates job opportunities, increase incomes and wealth, and can capture foreign exchange. The main challenge of forest policy is to make sure that forests and forest vocation lands contribute to maximize the welfare of society, and do it in a sustainable manner.

For analytical purposes, one may generally classify forest policies in two major groups. The first group includes those policies that are designed to increase the contribution of the sector to social welfare through the sustainable provision of private goods and services. These policies are concerned with the competitiveness of the production agents, increasing productivity, and improving the supra, inter and intra sectorial business climate wherein forest related entrepreneurs can operate and prosper, etc. They seek to grow and develop forest related businesses.

The second group of policies is concerned with the adequate provision of services for which no price is available, and therefore, the decisions of individual forest landowners do not take them into account in their decision making process. These services tend to be produced in smaller quantities than socially desirable or not at all. In addition, when misused, forest lands in fact may decrease social welfare, by the production of negative externalities that these misuses generate. This second group of policies seeks to reduce negative externalities and produce adequate levels of the services (positive externalities or public goods) that societies require.

Although addressing the second group of policies may actually help the competitiveness of the forest use of land, and therefore contributes to the goals of the first group of forest policies, it is useful to separate the two because they involve different but complementary rationality, policy instruments, and stakeholders.

This paper is mainly concerned with the second group of forest policies, i.e., those related with the reduction of negative forest based externalities and/or the production of positive ones. As such, it presents facts, defines concepts, examines analytical frameworks, and investigates policy alternatives related to these externalities in private lands.

It discusses and presents basic facts and frameworks about the externalities associated with lands covered with forests, such as externalities related to soil and water; biodiversity and genetic resources preservation; carbon sequestration and stock; and aesthetic, option and existence values. The paper demonstrates that each of these classes of externalities has specific characteristics that require different policy approaches to improve their provision. Given the nature of the forest vocation land methodology, it was possible to conclude that it could be useful to address soil and water related externalities (S\&WRE) in a simpler, more effective, and less costly manner when compared to alternative policy often used.

The relative impact of S\&WRE depends on the physical site features, and on the nature of the land cover or use. Not being unique to a few sites, these externalities are present anywhere the soil slope and length are high, soil has risk of eroding, rainfall has sufficient erosive power, land cover is not protective, and land use does not adopt conservation measures. These features require a forest policy solution that can be 
applied to all areas under risk usually distributed in many parts of a country. Forest policies based on the use of the forest vocation land methodology are shown to be effective alternatives to address these externalities.

The paper discusses land use planning methodologies and concepts which have been used frequently to identify sites for specific uses or having particular characteristics. Among the issues addressed here are the differentiation between the concepts of land cover and land use, soil and land classifications such as Agriculture Land Capability Classification, land capability classification for forestry, agro-ecological zoning, and ecological-economic zoning. A brief discussion of the economic implications of such land planning methodologies is also included. One of the conclusions reached was that these methodologies are costly; and require lots of data, manpower, equipments and materials to be properly applied. In the case of the most complex and sophisticated land classification methodologies, these costs can be substantial and almost unfeasible to be applied by the average developing country. However, they do allow an understanding of the factors and conditions determining S\&WRE, as well as help in the formulation of a framework for the design of public policies to address them. Therefore, it is an important challenge to identify the most efficient kind and degree of information that is needed and affordable by a given country that can best support the landowners' decision making and direct public sector interventions.

Next, the paper explores the use of a framework based on the vocation of lands as a strategic approach in the design and implementation of effective forest policies that improve the chances that society's welfare will not be adversely affected by negative forest based externalities. The classification of land according to its vocation is a prescriptive model that identifies the preferable general class of land cover that a given land area should have to assure that no soil or water related negative externalities occurs. It takes in consideration the area's basic physical characteristics of soil and topography (and sometimes rainfall, if relevant) which generally are not mutable over short time periods. It also assumes that no investments are made to effectively conserve water or soil resources, and, therefore, prevent the occurrence of related negative externalities and on-site fertility losses. Land vocation classification does not depend on the current land cover or use. It is a much simpler variation of the land classification methodologies and requires much less data and resources to be implemented.

To improve the understanding and applications of the vocation land methodology, the paper discusses the land rent model as applied to land use assignation. It shows the consistency among the two methodologies and the model's importance for the understanding of some economic issues related to forest vocation lands. The land rent model can help to explain, for instance, when landowners may find it to their advantage to assign a forest use to land, the consequences of additional costs associated with the adoption of soil and water conservation measures in agriculture production, as well as the consequences of externalities not being considered by the landowner; and what happens to land use choice if environmental services compensations are made for certain forest use of land.

The principal directive of a forest policy of the second group that is based on the concept of FVL is that they should be covered by forests or used with a sustainable land use if no negative S\&WRE are to reduce social welfare. When such requirement becomes law, landowners are limited in their land use alternatives so that only those that do not generate these types of externalities are acceptable.

Last, the paper explores and summarizes the implications for forest policy from the use of the forest vocation land methodology. The implications for the following issues are explored: biodiversity preservation; carbon sequestration and stock; illegality associated with management plans and custody chain controls; payments for environmental services; and poverty in the forest. It was explained, for example, the reasons why the requirements of licensing and management plans and the controls on the custody chain are not necessary to achieve society's goals when a FVL based forest policy is adopted. 
Forest vocation land is a useful model for the design of forest policies that seek to assure the provision of forest related externalities. Such policies are especially useful for developing counties because they are relatively easy to understand; are less intrusive in the forest business decision making processes and, thereby, allow for greater freedom of action; are less costly to monitor, enforce, and comply with; reduce corruptive activities and illegality associated with forests; and do not require adjustments as technologies and market conditions change.

The use of FVL based forest policies improves the effectiveness of state interventions that seek to address forest externalities issues and contribute to improve the competitiveness of forest businesses.

It is hoped that this paper will help to properly use and understand concepts and methodologies that can simplify and improve the forest policy debate that tries to make government interventions more effective, reduce illegality in private forest use, and redirect built in policy incentives so that landowners actively seek sustainable use of forest vocation lands. 


\section{Forest Based Externalities}

Understanding the nature of forest externalities is important because many forest policies are designed to assure their proper provision to satisfy society's needs and desires, the second group of policies mentioned above.

Forests affect welfare through the production and consumption of several goods and services. Some of these goods and services are traded in the market place where consumers and producers agree on prices, quantities, qualities, and other details of the transaction. Some other services produced by forests, however, are not exchanged on the market. Nevertheless, they may affect the social welfare as much as any private forest good or service.

Externalities are changes in a third party's welfare that result from decisions taken by someone who does not take in consideration such changes. When these decisions result in increase of the third party's welfare, it is said that a positive externality or external benefit has been generated. When these decisions result in decrease of the third party's welfare, it is said that a negative externality or external cost has been produced.

Forest based services not exchanged in the market result in positive externalities when landowners produce them, and result in negative externalities when landowners do not produce them. In either case, the welfare of local groups and/or global citizens not involved in the decision making will be affected.

Figure: 1: Causal diagram showing the linkages among an area covered with natural forests and welfare. ${ }^{1}$

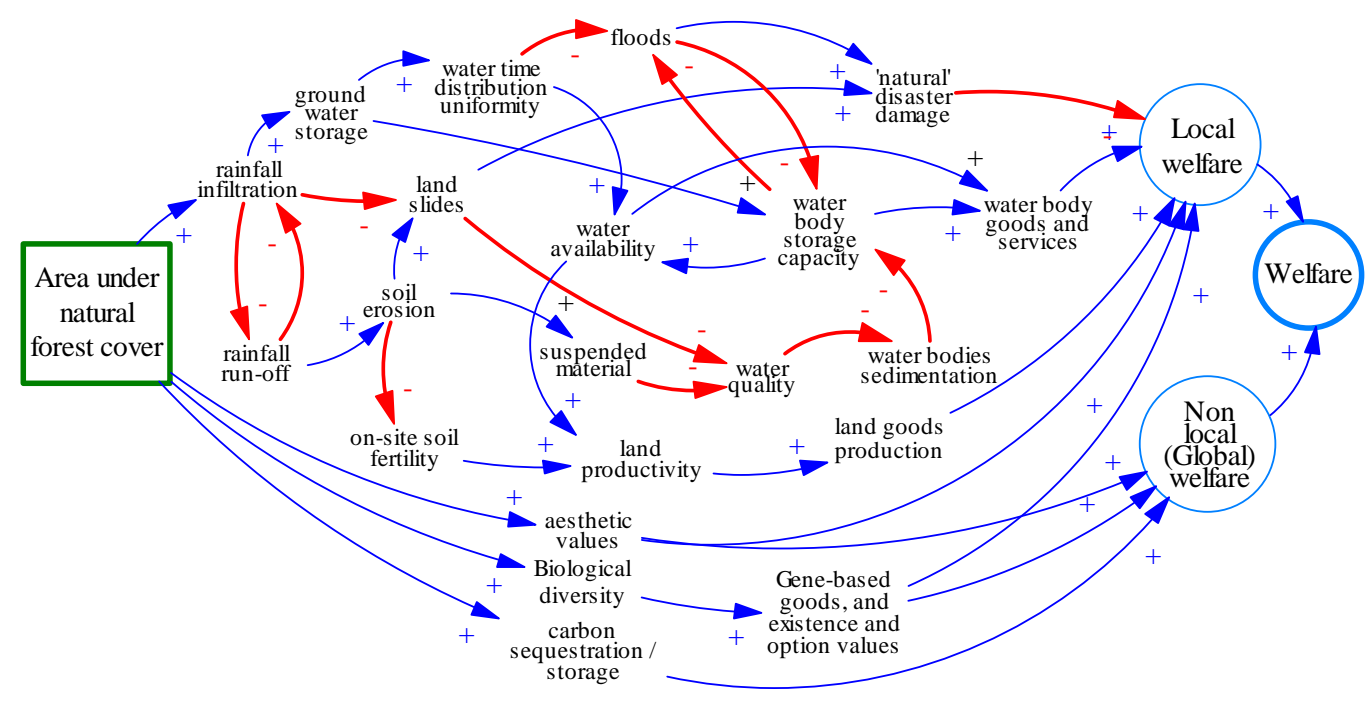

1 Variable $\mathrm{A}+$ Variable B This causal link indicates that as the value of variable A increases (decreases) it causes an increase (decrease) in the value of variable $B$, that is greater than it would occurs without the change in variable A. These variables change in the same direction.

Variable J - Variable K This causal link indicates that as the value of variable $\mathrm{J}$ increases (decreases) it causes a decrease (increase) in the value of variable $\mathrm{K}$, that is greater than it would occurs without the change in variable $\mathrm{J}$. These variables change in opposite direction. 
Figure 1 presents a diagram that summarizes the cause and effect linkages between lands covered with natural forest and the welfare of local or global consumers. It shows that welfare can be generally increased as more areas are covered by natural forests as this will generally increase soil and water conservation on important ${ }^{2}$ off-site benefits by increasing or keeping land productivity; increasing water bodies production of goods and services such as irrigation, hydroelectricity, water for domestic or industrial consumption; or by decreasing the adverse consequences of floods or land slides. Local welfare is also affected by the aesthetic, and existence and option values of forests. The latter service along with carbon sequestration and storage, and biodiversity preservation also affect the welfare on a global scale. Conversely, the reduction or removal of natural forest cover will lead to a reduction in welfare either by reducing the provision of positive externalities or by producing negative ones.

The existence of externalities related to forest means that landowners' decisions may not result in the welfare level desired by society. When deciding on the use of land, the economically rational landowner will, ceteris paribus, consider the conditions of the site, the private costs and benefits of alternative land uses, and select the one expected to be most profitable. As further discussed latter, to be selected, a forest use would have to be the most profitable alternative. As the externalities of forest cover do not enter the landowners' accounting neither as benefits nor as costs, it is expected that their decision will be different from what would be socially desirable.

It is important to differentiate the relative importance of these externalities in relation to some basic features of the land under natural forest cover as well as the nature of the forest cover itself. This clarification has important consequences for forest policy. On the hand, existence, option and aesthetic values; carbon sequestration or storage; and biodiversity preservation services usually are related more with the nature of the forest cover itself, regardless of the nature of the land supporting them. On the other hand, S\&WRE are linked to the physical features of the land underneath. Carbon sequestration or storage services are provided by natural forests as well any other type of forest cover or use, such as plantation, secondary, or managed forests, regardless of the site's particular features. While aesthetic values may be relatively flexible in relation to the type of forest cover, for biodiversity preservation to be effective it requires almost pristine forests in relatively large areas to assure the full benefits of their preservation over time (see section Biodiversity preservation externalities and forests). Therefore, not all forests are alike in terms of their contribution to welfare and not all externalities have the same requirements of forest cover kind and degree to satisfy a certain social need or desire. These differences need to be kept in mind by policy makers when addressing the forest based externalities issues.

The reminder of this section discusses important aspects of the externalities associated with soil and water conservation, biodiversity preservation, and carbon sequestration and stocks. The objective is to give a basic understanding of the way these externalities are produced and the basic characteristics that may determine the alternative policy alternatives to promote their adequate provision.

\section{Soil loss related externalities and forests}

Erosion results on the reduction of on-site productivity of the land because of the losses in soil nutrition and of the adverse changes in its physical characteristics, which reduces water availability for plant consumption. It also generates the off-site S\&WRE mentioned above. Cover is an important factor

\footnotetext{
${ }^{2}$ Initially, governments were motivated to stem soil losses because of concerns over the effects that erosion might have on crop yields. In recent years, however, they have come to realise that off-farm damage caused by the transport of soil particles - especially those related to the build-up of silt in rivers and dam reservoirs - often exceeds that which takes place on farms (Steenblik, Ronald, Leo Maier, and Wilfrid Legg. 1997).
} 
determining the erosion rate of a given land site. Forests are one of the most protective types of soil covers that can help soil loss reduction.

However, as figure 2 shows, several other factors also influence the rate of soil erosion in a given site. The importance of the forest cover role will depend on the specific conditions found on a particular site. According to the Universal Soil Loss Equation model, one of the most traditional ones, the principal factors that affect soil erosion are rainfall, slope length, slope steepness, soil erodibility, the nature of the cropping or management system or cover, and the soil and water conservation practices adopted (See Sfeir-Younis and Dragun, 1993; and NRCS, 2000 for further details). The model estimates that soil loss will be greater in situations where rainfall and soil erodibility are greater, surface slope gradients are more pronounced and lengthier, soil cover are reduced, and no conservation practices are adopted. The stock of soil affected by substantial erosion rate can, over time, be converted to degraded soil and, if not restored, eventually result in a desert ${ }^{3}$. As a consequence of the erosion process, sediment material is deposited in other parts of the landscape, water infiltration diminishes, and runoff increases.

It is important to notice that features such as rainfall, topography and soil erodibility are site specific physical and climatic conditions that cannot be easily (cheaply) modified by man. On the other hand, soil loss from a given site can be affected by common production decisions taken by landowners when they select the type of cropping or management system to apply (and, hence, the type of cover the site will have), or whether to adopt soil and water conservation measures to protect it. These measures and adjustments would be essential for sustainable production, especially in sloping lands (Fischer, van Velthuizen, Shah, and Nachtergaele, 2002).

Figure 2: Descriptive model of factors affecting the erosion rate, as proposed by the Universal Soil Erosion Equation.

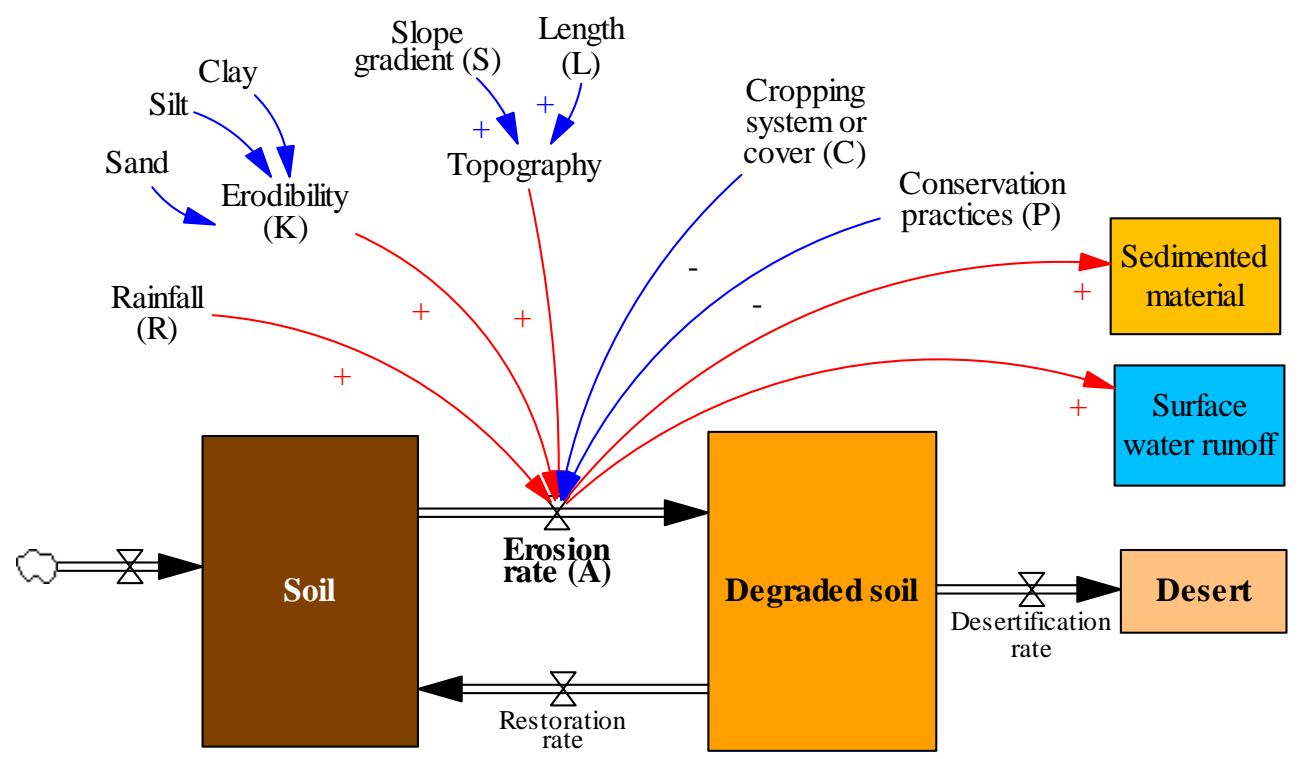

Note: Prepared by the author based on Sfeir-Younis and Dragun (1993); and NRCS (2000).

Combined with a basic understanding of economic decision making, this model provides a good indication of when forest use would the most appropriate for a given site. When deciding on how to use a

\footnotetext{
${ }^{3}$ Figure 2 was meant to clarify the soil loss process, and therefore, does not discuss the factors that affect the restoration and desertification rates.
} 
given piece of land, the economically rational landowner will, ceteris paribus, consider the natural physical and climate conditions of the site, the private costs and benefits of alternative land uses (cropping or management system or cover, and conservation practices), and select the one expected to be most profitable over time. Therefore, to be selected, forest use (cover) would have to be the most profitable alternative. As the positive externalities associated with forest cover or the negative externalities associated with alternative land uses do not enter the landowners' accounting, it is expected that their decision will be different from the one that would be socially desirable.

As figure 1 indicated, soil loss processes are intimately linked with water conservation issues. These water related externalities affect the welfare of society though services such as the ground and water bodies' water stocks over time for the production of goods and services or consumption, and the reduction of the risks of some floods and land slides events.

\section{Biodiversity preservation externalities and forests}

Biodiversity can be a broadly defined concept that involves the provision of many goods and services (see box 1). However, the discussion of biodiversity preservation benefits and forest in this section concentrates on issues related to in situ genetic resources. Biodiversity here contributes to the welfare of society because it is a depository of genetic resources that can sustain or increase the productivity or production of many different types of goods, from improved genetic animals or plants, to pharmaceutics and other industrial products that can improve human welfare everywhere (Ledec and Goodland, 1988; McNeely, et al., 1990).

Although most of the goods produced based on genetic resources are private and their prices reflect their relative scarcity, the genetic resources that allowed them to be produced usually do not have market prices and are externalities for which the landowner in whose lands the resources are found are rarely compensated for (OECD, 2004a).

It should be noted that the preservation of genetic resources also assures the provision of existence and option values, because they are jointly produced services. Existence and option values of forest ecosystems cannot be provided completely, except by the preservation of genetic resources in situ. Hence, if genetic resources are properly preserved, existence and option values will also be properly provided for.

Lack of complete knowledge about existing genetic resources makes their preservation important not only because of existing uses but also because of the potential uses yet to be developed. 
The perpetuation of ecosystems is fundamental for the preservation of the genetic resources. The genes existing in a given specimen may vary slightly from those of other specimens, and substantially from those of other species although some overlap can exist among species of the same taxonomic group. Genes may also change over time, which is the basis for the evolutionary process. The dynamic survival of genes depends on the survival of specimens, that in turn depends on the survival of the species where it is found, which depends on the survival of the ecosystem where the species evolved in and prospered (McNeely et al., 1990). Figure 3 presents the relationships among genetic resources and the respective specimens, species, and ecosystems; while box 1 presents some basic concepts used in this paper.

Genetic resources can be preserved ex-situ, but this solution is not feasible for all species, does not allow the natural evolution process to take place, and, hence, need to be combined with in-situ conservation approaches. The preservation of at least a representative and functional sample of each existing ecosystem in a size sufficient to allow its self perpetuation over time without losing any species besides those losses resulting from natural processes, is fundamental for the preservation of genetic resources. As McNeely, et al., (1990:

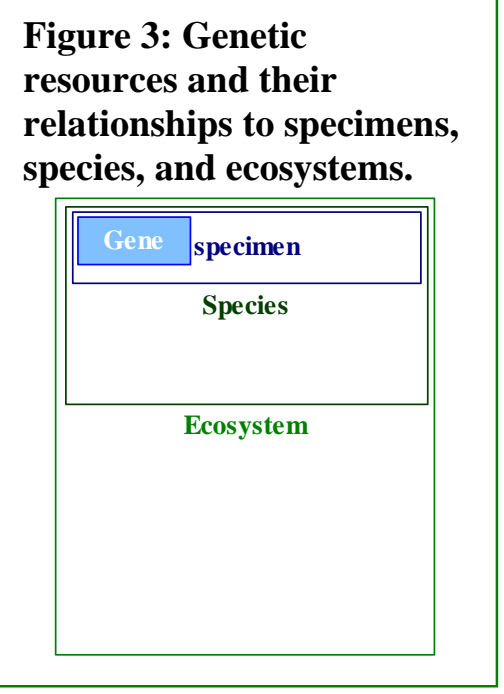
57) put it

While a number of species protection measures have been effective and emergency speciesspecific action is often required to prevent extinction, species are best conserved as parts of larger ecosystems where they can continue to adapt to changing conditions as part of their respective communities.

Not all ecosystems are alike, although all are important because there is no way of knowing beforehand which genes from which species from which ecosystem will be the ones that will allow the development of a drug treatment for the cure of some important disease or of other important product.

\section{Biological diversity and forest ecosystems}

Forest ecosystems are recognized as important reservoirs of genetic resources and are at increasing risk. Primary tropical forest ecosystems, e.g., are among those which host the most number of different species and are considered of critical importance as a depositary of biodiversity. Forest ecosystems, however, have been disappearing rapidly, risking the loss of the corresponding genetic resources. A recently published study by FAO, found that about 13 million hectares of forests are being deforested per year and converted mainly to agricultural land uses with substantial loss of specimens and perhaps some species (FAO, 2005b). Therefore, there has been urgency in trying to preserve genetic resources from forest ecosystems before they have been irreversibly modified and more species lost.

The deforestation process has resulted in the fragmentation of the forests in island-like areas whose size frequently are smaller than those needed to sustain functioning ecosystem, resulting in their deterioration and affecting their role in maintenance of their genetic resources stock (Bawa and Seidler, 1998, Lawrence, 1999). The smaller the fragments are, the greater the exposed perimeter and the risks for species survival in the remaining area. If the affected species are not protected elsewhere, this process can lead to species extinction.

Besides the reduction of size of the ecosystem affected, fragmentation has another important consequence which further affects the sustainability of affected ecosystems; it generates adverse edge effects. Edge 
effects result from the exposure to very different ecological conditions that species have to face at the edges or perimeters of the fragmented area. While some species may prosper in those areas, there is important evidence that suggest that many species do not survive these changes, resulting in important modification of species composition (Lawrence, 1999). Besides, the edges tend to expand the deteriorated area further reducing the size of the remaining forest fragments, which seems to indicate a vicious circle that can lead to its drastic reduction in size. These evidences put in question the feasibility of preserving genetic resources present in complex ecosystems in smaller fragmented areas or areas subject to disturbances large enough to provoke edge effects.

The protection of large enough areas used to be promoted by the conservation community up to the 1980 s, as the principal way to assure the preservation of genetic resources. However, the difficulties to find and keep such areas free from human occupation, and the sense of urgency felt due to the continuing destruction or deterioration of forest ecosystems, seem to have led the conservation and development organizations to change strategy. They started to promote a strategy that seeks to reconcile the use of forest resources and the preservation of species thorough an ecosystem management approach (Sayer, Vanclay, and Byron, 1997). This approach has acquired many supporters and, indeed, has been adopted by many international organizations and sanctioned in the Convention on Biological Diversity (FAO, 2005a).

One of the variations of this new strategy is the Natural Forest Management (NFM) system which hopes to reconcile logging with forest genetic resources preservation. The accumulation of evidences questioning the technical feasibility of using biological resources at same time as trying to preserve the genetic resources of the primary forest ecosystem has led some to question the wisdom of such strategy. Bawa and Seidler (1998: 47), for instance, have concluded "...that emphasis on NFM as a means to sustainably use tropical forests and to conserve biodiversity is not supported by the available evidence and that there is a danger this emphasis may be detracting from other options available for conservation, management, and utilization of tropical forest resources."

In addition, the technical requirements of NFS are likely to make it more expensive to manage forests and/or reduce benefits by limiting resource use alternatives. This reduced profitability may in fact make NFS less attractive to landowners and lead to the reverse reaction that may result in the conversion of the forest covered lands to others uses for which society has no or minimum use restrictions. Therefore, the additional genetic resource preservation objective is likely to reduce forest use competitiveness.

It seems that a precautionary approach for the sustained provision of the genetic resources externalities associated with natural forest ecosystems is to establish a system of conservation units that include representative and sustainable samples of each of the forest ecosystems (indeed all types of ecosystems) of a country. Solutions that depend on small fragmented ecosystems generally are less adequate to protect sufficiently big enough samples of ecosystems so as to assure their continuous existence over time. Restricting use of some fragmented areas with natural forests in buffer zones may be useful only if they are effective in the protection of the perimeter of such protected areas so as to reduce the impact of the edge effect. As further discussed below, these restrictions imposed on landowners' alternatives to use land need to be compensated properly so as to assure their cooperation.

In sum, the genetic resources found in forest ecosystems contribute substantially to local and global welfare. Their preservation in areas that are sufficiently large to sustainably protect all species found therein is an important necessary and, perhaps, sufficient strategy to assure the preservation of these genetic resources. Obviously, other sustainable land uses that can be competitively sustained and keep a large number of species, such as secondary forest management, agroforestry, etc, can contribute to this effort, but they are not sufficient, and may be, not even necessary for the purpose of genetic resources preservation. Thus, genetic resources preservation is ecosystem specific and not site specific. That is, to 
assure the preservation of these resources it is not feasible to simply preserve any piece of forest ecosystem regardless of the level of use it has had, or its size.

\section{Carbon sequestration and stock, and forests}

Atmospheric carbon dioxide $\left(\mathrm{CO}_{2}\right)$ is one of the greenhouse gases causing the warming of the planet. Forests, independent of their location, make two basic contributions to reduce it in the atmosphere. Regardless of whether they are primary or secondary natural forests, planted with native or introduced species, through photosynthesis, they all sequester atmospheric carbon gas and deposit it in biomass stocks. While carbon is stored in wood stocks and other forest biomass, it is contributing to reducing the damaging stocks in the atmosphere. However, besides the natural respiration process that live plants perform, these stocks can be an important source of $\mathrm{CO}_{2}$ if wood in forests or forest products are burned, or decay. Figure 4 presents a descriptive model that illustrates some of the factors that affect carbon stocks, and its sequestration and emission flow rates as related to forests.

Figure 4: Some factors affecting forest related carbon stocks, and sequestration and emission rates.

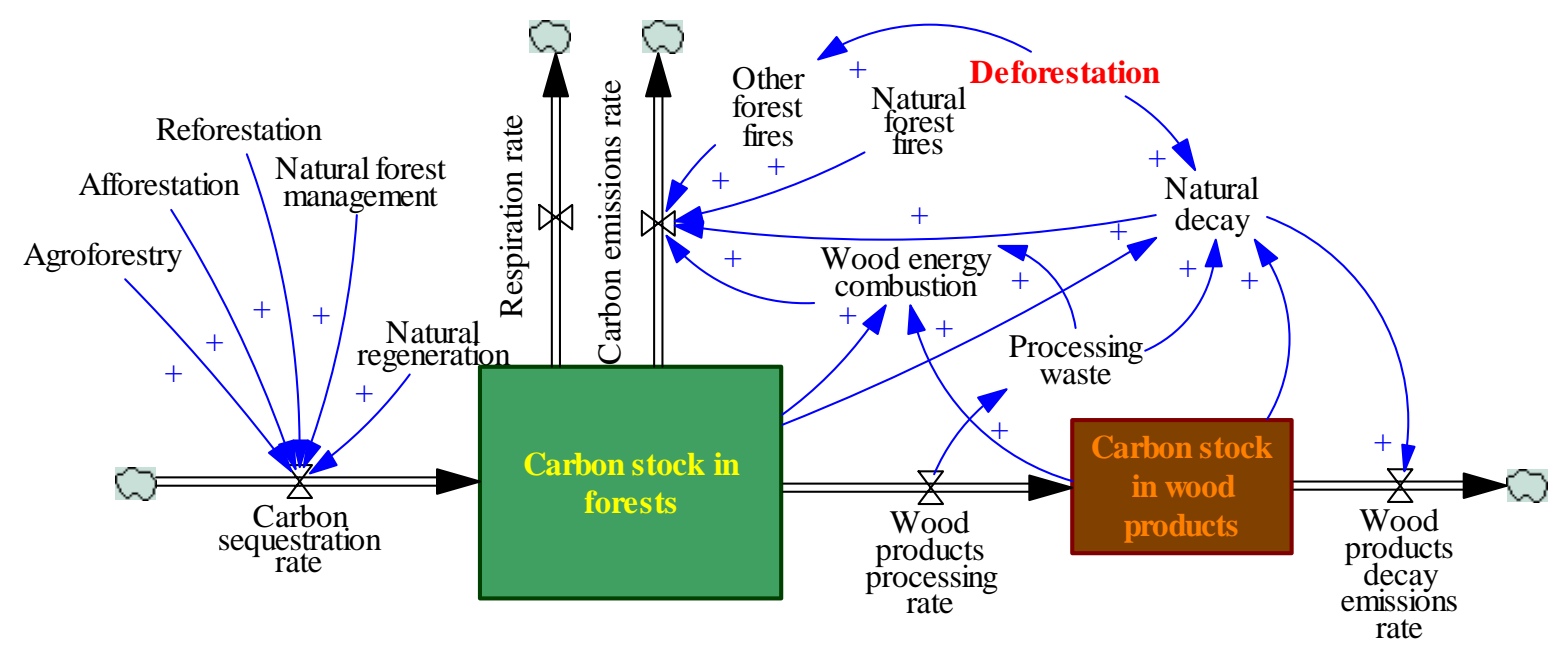

In a recent study, FAO has estimated the quantity of carbon accumulated in the forest biomass as well as its relative importance. It found that ... the amount of carbon stored in forest biomass alone is about 283 Gigatonnes (Gt) of carbon... . Carbon stored in forest biomass, deadwood, litter and soil together is roughly 50 percent more than the amount of carbon in the atmosphere. FAO (2005b).

These roles of sequestrating and storing carbon are, for the most part, not considered by landowners in their decision making. The Kyoto Agreement has tried to create the opportunities for the internalization of these forest based externalities. It is expected that mechanisms such as the trade of carbon credits, would allow landowners to be compensated for sequestrating carbon as they use their land resources for the production of biomass; as well as for maintaining carbon stocks in the biomass by reducing deforestation that results in emissions. If this internalization is fully accomplished, it would convert this forest environmental service into a private service traded efficiently in the market place. This would, therefore, overcome the externality type of forest policy concern and convert the issue into the first forest 
policy group since the sale of this service would make the related forest businesses more feasible and attractive as investment. As of now, this internalization has had limited actual impact on the decision making of most landowners for reasons that go beyond the purpose of this paper to discuss.

\section{Basic features}

Table 1 summarizes some basic features of the forest related externalities in relation to uniqueness; ubiquitous nature; physical site dependence; general or particular cover or use dependence; and the principal beneficiaries. It is fundamental to keep in mind these basic features when designing forest policies which seek to assure the provision of external benefits to improve the social welfare and avoid negative impacts.

Aesthetic externalities are usually based on a unique feature of the forest landscape, and therefore need to be addressed by policies that are of local impact. In addition, for the most part, for locals and other users to benefit from them directly, they need to be present locally. This fact indicates that, if exclusion of non payers is possible, locals and visitors could be charged to enjoy such benefits. There is no need for a policy that affects many landowners when the only affected ones should be those directly involved in the locality where it occurs. It is beyond the purpose of this paper to further discuss this type of forest externality or the policies that may assure its adequate provision, besides noting that in

Table 1: Basic features of forest related externalities.

\begin{tabular}{|c|c|c|c|c|c|}
\hline & Basic Features & & Exte & alities & \\
\hline Type & Definition & Aesthetic & $\begin{array}{c}\text { Carbon } \\
\text { seq./ } \\
\text { stock }\end{array}$ & $\begin{array}{l}\text { Biodiver. } \\
\text { related }\end{array}$ & $\begin{array}{c}\text { Soil and } \\
\text { water } \\
\text { related }\end{array}$ \\
\hline Uniqueness & $\begin{array}{l}\text { The externality is associated } \\
\text { with situations that are unique } \\
\text { or present in very special } \\
\text { places. }\end{array}$ & Yes & No & Yes & No \\
\hline Ubiquitous & $\begin{array}{l}\text { The externality may be present } \\
\text { in most situations }\end{array}$ & No & Yes & No & Yes \\
\hline $\begin{array}{l}\text { Physical site } \\
\text { features } \\
\text { dependent }\end{array}$ & $\begin{array}{l}\text { The externality production } \\
\text { varies in accordance to basic } \\
\text { physical features of the site, } \\
\text { such as topography, soil } \\
\text { erodibility; climate. This type } \\
\text { of feature is independent of } \\
\text { cover or use issues. }\end{array}$ & No & No & No & Yes \\
\hline $\begin{array}{l}\text { Cover or use } \\
\text { dependent: } \\
\text { General or } \\
\text { Particular }\end{array}$ & $\begin{array}{l}\text { The externality varies with the } \\
\text { type of land cover or use. The } \\
\text { land cover or use dependence } \\
\text { may be general if a broad } \\
\text { category is sufficient (like } \\
\text { forest cover), or particular, in } \\
\text { case the cover or use needs to } \\
\text { have a special feature. }\end{array}$ & Particular & General & Particular & General \\
\hline $\begin{array}{l}\text { Principal } \\
\text { beneficiaries: } \\
\text { Local or } \\
\text { Global }\end{array}$ & $\begin{array}{l}\text { The principal beneficiaries of } \\
\text { the externality can be persons } \\
\text { from the location where it is } \\
\text { produced or from other } \\
\text { regions or countries, from the } \\
\text { globe. }\end{array}$ & Local & Global & Global & Local \\
\hline
\end{tabular}
many instances a market based solution may be created to internalize it.

Carbon sequestration and stock externalities, in contrast, are not unique to a specific situation or site and can be produced by growing forests almost anywhere they can be grown; they are ubiquitous in terms of where they can be produced. In fact, they are not exclusively produced by forests since there are several strategies to attack this problem, such as reducing emissions from vehicles or industries. These externalities benefit humanity in general and not a specific group. This imply that forest policies concerned with carbon related externalities also are not site relevant and should seek that the global 
beneficiaries pay for them. The Kyoto mechanism seeks to create a framework where these payments can take place. Here also it seems that the market system can be adjusted to allow the internalization of $\mathrm{CO}_{2}$ related forest externalities.

Genetic resources preservation depends on the preservation of effective samples of unique and fully functioning ecosystems where they are found. Their preservation depends neither on the physical nature of the site, nor on any forest cover, but rather on a very particular type of forest cover, an untouched forest ecosystem. Hence, any forest use may result in the partial destruction over time of the resource. Even though some of these resources seem to be present ubiquitously, especially in natural forest areas, the effective protection of all generic resources of an ecosystem is feasible only by the protection of specially selected areas where samples of these ecosystems can be set aside and protected. Fragmented areas covered in part or totally by natural forests cannot serve as a basis for a prudent policy for the preservation of genetic resources because they keep degrading over time inevitably reducing their genetic preservation value. To be covered by natural forest is neither sufficient nor necessary to assure the preservation of the genetic resources found therein. Compensated restrictions on land use in natural forest areas located in buffer zones around protected areas, however, may be a useful complementary strategy to help in the long term maintenance of the protected areas.

S\&WRE have a combination of features that require a particular approach to assure their adequate provision to society. The importance of these externalities depends on the physical site features, which can be found nearly ubiquitously, and on the nature of the forest cover or use. Not being unique to a few sites, these externalities are present anywhere the soil slope and length are high, soil has risk of erosion, rainfall has sufficient erosive power, land cover is not protective, and land use does not adopt conservation measures. These features require a forest policy solution that can be applied to all areas under risk which often are distributed in many parts of a country. In addition, the beneficiaries of such externalities are in part the landowners themselves, but also the local society. The benefits may cross country borders, but this special situation is not addressed here. 


\section{Land Use Planning}

The purpose of this section is to clarify concepts, provide an understanding of the main features of land that affect production, productivity and externality, and contrast the several ways in which land can be classified, especially as compared with vocation land classification. Land classifications are policy instruments frequently mentioned in forest regulations and for that reason they will receive greater attention here. The paper discusses the concepts of land cover and land use, presents descriptive and prescriptive models related to soil and land use planning, including agriculture land capability classification, land capability classification for forestry uses, agro-ecological zoning, and ecologicaleconomic zoning methodologies. It also discusses the economic aspects of soil and land classifications. Lastly, it presents the vocation land classification, particularly the definition of forest vocation, the principal concept being explored in this paper because of its potential role in design of forest policies of the second group.

\section{Land cover and land use}

The concepts of land cover and use are very simple; nevertheless, they refer to important ideas that can be useful in the discussion about forest policies.

Land cover is the observed (bio) physical cover of the earth's surface, regardless of its use by people. The precise typology of land cover depends on the purpose of the classification and on the regions where it is supposed to be applied. Some examples of land cover types are the various types of forests, grasses, croplands, bare land, water bodies, etc. (see formal definition in box 2). Consequently, areas where the surface consists of bare rock or bare soil are describing land itself rather than land cover. Although some may dispute whether water surfaces are real land cover, in practice, the scientific community usually considers them as such (Di Gregorio and Jansen, 2000).

\section{Box 2: When does an area have a forest cover?}

FAO (2004) counts as forest, land that spans

"more than 0.5 hectares with trees higher than 5 meters and a canopy cover of more than 10 percent, or trees able to reach these thresholds in situ. ... Explanatory notes:

1. Forest is determined both by the presence of trees and the absence of other predominant land uses. The trees should be able to reach a minimum height of 5 meters in situ. Areas under reforestation that have not yet reached but are expected to reach a canopy cover of 10 percent and a tree height of $5 \mathrm{~m}$ are included, as are temporarily unstocked areas, resulting from human intervention or natural causes, which are expected to regenerate.

2. Includes areas with bamboo and palms provided that height and canopy cover criteria are met.

3. Includes forest roads, firebreaks and other small open areas; ... .

4. Includes windbreaks, shelterbelts and corridors of trees with an area of more than 0.5 ha and width of more than $20 \mathrm{~m}$.

5. Includes plantations primarily used for forestry or protection purposes, ... .

6. Excludes tree stands in agricultural production systems, for example in fruit plantations and agroforestry systems. ..."

For the purpose of this study, forest cover includes the tree stands in agricultural production systems mentioned in note 6 .

Land use is, in turn, characterized by the arrangements, activities and inputs people undertake in a certain land cover type to produce, change or maintain it. The definition of land use in this way establishes a direct link between land cover and the actions of people on their environment. The following examples provide further illustrations of the meaning of land use: "grassland" is a cover term, while "rangeland" or "tennis court" refer to the use of a grass cover; and "recreation area" is a land use term that may be 
applicable to different land cover types: for instance sandy surfaces like a beach; a built-up area like a pleasure park; woodlands; etc. (Di Gregorio and Jansen, 2000).

These concepts are useful in the design of policy. For example, a legal requirement for landowner to keep a certain piece of land under forest cover is quite different from commanding forest use. The first is a very flexible concept since it would require only that landowner keep at least certain quantity of trees sufficient to characterize forest cover. It does not ask for any type of species or other characteristic, and can usually be easily complied with by natural regeneration (or, in some cases, the simple abandonment of the area), plantation of native or exotic tree species, agroforestry, coffee and other arbustive species, or protection of existing natural forests. This requirement is relatively simple to monitor either in the field or remotely, and it is non discretional as it is easily understood by the landowner, government official and other stakeholders. There is no need for any process verification since the existence of the forest is the indicator that verifies compliance.

A legal requirement for a landowner to keep a certain piece of land under forest use as is usually the case under norms that require the implementation of a management plan, on the other hand, would demand a much more complex set of criteria to determine compliance. If there is a natural forest cover in existence, either as a product of natural regeneration or a secondary forest, the owner would have to demonstrate the use of silvicultural practices, which may be difficult to be verified in the field. In this case, there is almost a need for process verification to justify compliance since ex-post inspections may not be able to detect sufficient evidences to demonstration violations. These situations are often more discretional and expensive to comply with and to monitor.

\section{Soil and land classifications}

There are two basic ways to describe or classify soil: a natural and a technical. The first is based on some natural feature of the soil, such as its genesis or the ecological region where it is found. This classification of soils is based on soil properties defined in terms of soil horizon diagnostics and other characteristics measurable or observable in the field; and takes into account their relationship with soil forming processes. The natural soil classification based on genesis yield soil types such as vertisols, podzols, andosols, and arenosols (see UNESCO, 1974 ${ }^{4}$ ). This type of classification does not take in consideration soil use issues. (FAO, ISRIC, and ISSS, 1998; EMBRAPA Solos, SD; Rossiter, ND; Rossiter, 2001)

The second way to classify soil is based on some technical property or function related to a use or group of uses of interest and involves variables such as hydrological response; suitability; capability; fertility; etc. There are several systems of land classification in use which vary according to the classification objectives, and the lands' present use, suitability for a specific crop or combinations of crops under optimum or existing forms management systems, or suitability for non-agricultural types of land use. For the purposes of this paper, two technical soil classifications for land capability assessments are briefly discussed; one for agriculture and the other for forestry uses. These types of technical classification are indeed prescriptive models because they seek to determine for a give-n area, the most suitable land use which does not cause undue danger of soil degradation.

\section{Agriculture Land Capability Classification}

Agriculture land capability assessment is an interpretive and somewhat subjective system for the ranking of the ability of a site to support a range of selected crops without generating negative externalities or onsite negative impacts. The soils are grouped according to their limitations for selected crops, the risk of

\footnotetext{
${ }^{4}$ See reproduction in http://www.fao.org/ag/agl/agll/key2soil.stm
} 
damage if they are used for such crops, and the way they respond to management. Major land forming activities that would change slope, depth, or other characteristics of the soils, or major reclamation are not considered in the classification.

Table 2: Sustainable land uses per land capability class

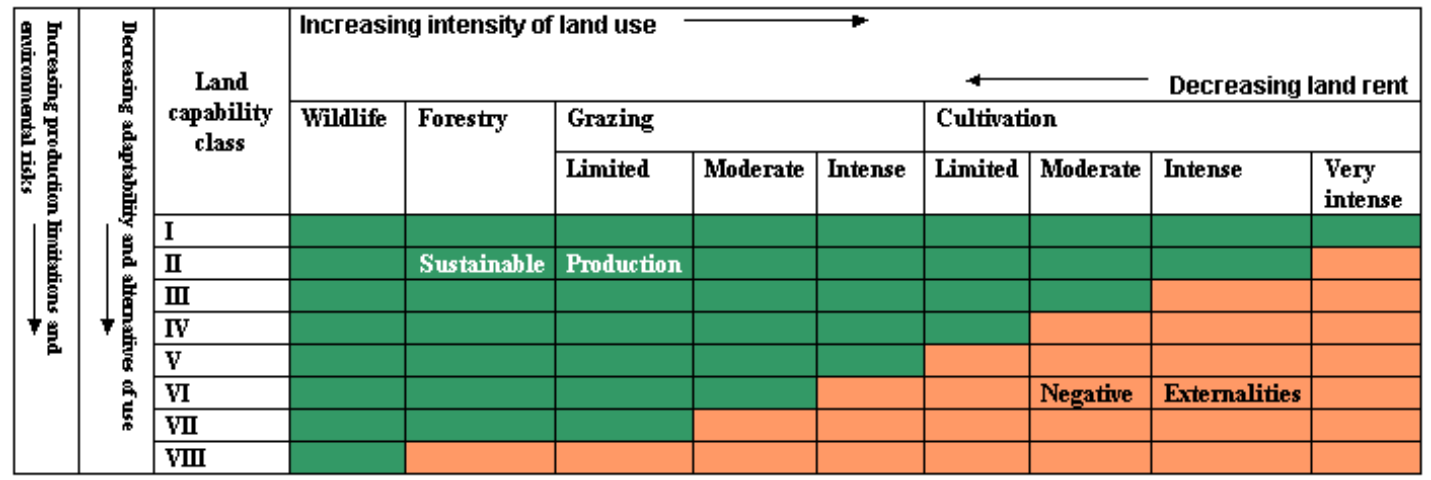

In many cases, there are 7 or 8 principal classes of agriculture production capability distributed in a range from the least limited to severely limited capability for crop agriculture production. One of the most traditional and best known agriculture land capability classifications is the United States Department of Agriculture system. Table 2 illustrates this system, where the columns in its main part indicate different land uses from very intensive agriculture annual crop cultivation to very low intensive use such as wildlife where landowners may be limited to the protection against fire or other non consumptive related activities. The lines show soil or land capability classes varying from I to VIII, where soils in class I have the least limitations, minimum environmental risks of generating water and soil externalities, and is adequate to the requirements of all land uses. On the other extreme of the land capability scale, class VIII is the most restrictive type of use that can be made without generating these types of negative externalities. Further explanations for each class can be found in Box 3 .

As land capability classes go from I to VIII, the alternative land uses are fewer, production limitations increase, and environmental risks are greater. The use of a given land capability class with a land use that is more intense than recommended by this model, is expected to generate negative S\&WRE to the whole of society and on-site losses of soil productivity for the landowners, unless they invests in effective soil and water conservation measures.

Though the model is useful to identify the potential production and environmental impacts of different land uses in different land classes, it has little to say about which

\section{Box 3: USDA principal land capability classes.}

Class I soils have few limitations that restrict their use.

Class II soils have moderate limitations that reduce the choice of plants or that require careful management. Land identified as Class IIe, for example, would be suitable for growing crops if adequate measures were installed to reduce or prevent soil erosion.

Class III soils have severe limitations that reduce the choice of plants, require special conservation practices, or both.

Class IV soils have very severe limitations that reduce the choice of plants, require very careful management, or both.

Class $\boldsymbol{V}$ soils are not likely to erode but have other limitations, impractical to remove, that limit their use largely to pasture or range, woodland or wildlife.

Class VI soils have severe limitations that make them generally unsuitable for cultivation and limit their use largely to pasture, range, woodland, or wildlife.

Class VII soils have very severe limitations that make them generally unsuitable for cultivation and limit their use largely to pasture, range, woodland, or wildlife.

Class VIII soils and miscellaneous land types have limitations that preclude their use for commercial crop production and restrict their use for recreation, wildlife, water supply, or esthetic purposes.

Source: NRCS, 2000. 
land uses are the most likely that to be chosen by landowners facing a given situation. For that type of decision, it is necessary to take in consideration economic factors.

Box 4 presents some interesting consequences for forest policy from the framework and hypothesis supported by the agriculture land capability classification methodology.

\section{Land capability classification for forestry}

In the case of land capability classification for use in forest production, the classes are related to the conditions necessary for tree crops. It tells the user where one can expect that forest production can be more productive. Classes generally vary from land with excellent flexibility for the growth and management of tree crops to land unsuitable for commercially producing tree crops due to unfavorable climate; wetness (flow-bog or flood sites), rockiness and/or extreme slopes (see examples for Canada in McCormack (1967); and for Brazil in EMBRAPA Solos (1999)).

\section{Box 4: Forest policy relevant consequences from agriculture land capability classification.}

Using this prescriptive model, one can explore some interesting consequences relevant for forest policy.

1. The agricultural use of soil classes for which it has increasing limitations, generates environmental direct (on-site) and indirect (off-site) negative impacts indicated in table 2 by the color orange.

2. Agriculture production cost increases and land rent decreases as agriculture capability decreases.

3. Ceteris paribus, even not considering the externalities, it is expected that landowners misusing their lands in classes (IV-VII) for agriculture production would yield smaller benefits than producers in land classes I-III

4. Forest use is increasingly more appropriate for land classes greater than III.

5. In class VIII, even forest use is too costly to be undertaken and therefore cannot compete with other better-located forest production-sites. These areas are usually left for wildlife use.

6. Unlike agricultural land use, forest use is very flexible and is suitable to most agriculture capability classes, although with varying productivity and production costs.

7. The classification reserves for wildlife (class VIII) only the most unproductive and environmental sensitive areas. Although these areas may provide adequate protection for some species and ecosystems, it is just a by product from the model since it was designed with production consideration in mind and not biodiversity preservation.

\section{Agro-Ecological Zoning}

Agro-Ecological Zoning (AEZ), is a complex methodology that seeks to enable rational land-use planning, management and monitoring on the basis of an inventory of land resources, and an evaluation of biophysical limitations and potentials for specific crop production and crop production requirements. It tries to divide land into units with similar crop suitability, productivity potential and environmental impact.

This zoning methodology is a prescriptive model that tries essentially to determine what can be produced in a given area considering its natural characteristics and the requirements of crop land uses. As byproducts of this basic purpose, AEZ can also be used in various assessment applications, including: land resource inventory; inventory of land utilization types and production systems, including indigenous systems, and their requirements; potential yield calculation; land suitability and land productivity evaluation, including forestry and livestock productivity; estimation of arable areas; mapping agroclimatic zones, problem soil areas, agro-ecological zones, land suitability, quantitative estimates on potential crop areas, yields and production; land degradation assessment, population supporting capacity assessment and land use optimization modeling; assessing and mapping flood and drought damages to crops; assessment of impact of climate change; and monitoring land resources development (FAO, S/d-a).

The usefulness of AEZ comes with an expensive price tag. It involves complex methodologies, and has 
substantial requirements that few developing countries can easily afford on a sustained basis. To be implemented properly, it needs financial , geo-referenced databases of several soil, and terrain characteristics that affect agriculture production (topography; administrative boundaries; road/ communications; towns and settlements; rivers/water bodies; geology; soil; physiography; landform; erosion; rainfall; temperature; moisture regime; watersheds; irrigable areas; land use/land cover and forest reserves; population); the development of crop modeling and environmental matching procedures (for the calculation of length of growing period, irrigation requirements, crop biomass, land suitability, land productivity), and the use of decision tools. That implies the need for substantial financial resources, equipments and specialized personnel.

In addition, AEZ has no consideration for the economic factors that affect land use decision making neither is it easily updatable to take in consideration the changes in technology as they become available. Forest use in these exercises has been considered as a productive land use. Indeed, forest cover has been considered a limitation since forest ecosystem conversion to other land uses has been considered undesirable, especially tropical forest ones (FAO, 2000). In the case of a major global AEZ exercise, the authors were able to calculate the lands with agriculture crops cultivation potential that were covered by forest ecosystems.

As an example of combining AEZ results with spatial land-cover information, the extent of land with cultivation potential presently under forest ecosystems was estimated ... . Our estimation suggests ... that (for the entire world) close to $19 \%$ of the land with cultivation potential ... is under forest ecosystems (i.e., 464 million ha out of a total with cultivation potential of 2,430 million ha). A similar share, 17\% (i.e., 237 million ha out of 1,380 million ha), holds for very suitable and suitable lands. On a regional scale, the largest shares of land with crop production potential currently under forest are found in South and North America, where more than one third of the potentially cultivable land determined by AEZ is classified as dominantly forest ecosystems .... .... Our results indicate that relatively more land with cultivation potential for major cereals is covered by forest ecosystems in developed countries (about 23\%) than in developing countries (about 17\%). (Fischer, van Velthuizen, Shah and others, 2002: 98-9).

Furthermore, when individual countries are analyzed, the contrasts among them are likely to be very relevant to understand forest and biodiversity preservation policies. Take the case of Suriname, for instance. There, $84.6 \%$ of the potentially cultivatable lands were under forest ecosystems, but these lands represented less than a third of its total forest ecosystems. Uruguay, on the other hand, has less than $1 \%$ of its cultivatable lands under forest ecosystem cover while these lands represent $70 \%$ of the total area covered by these ecosystems, making their preservation likely to be very important. For the case of Brazil, a country frequently on the news due to the rates of deforestation that happen there, the study found that $43 \%$ of its forest ecosystems were covering potentially cultivatable lands, while these ecosystems represent less than a third of the then existing forests. It should be noticed, that these forest ecosystem areas exclude those forests already defined as protected areas. Table 3 presents, for select LAC countries, the land potential for rain-fed cultivation of major cereals under forest ecosystems.

Undertaking AEZ is an expensive exercise whose benefits for some purposes may not justify the costs. Of course, the fact that AEZ can have several uses does not mean that they are all equally needed to address a specific policy situation. For the purpose of a forest policy concerned with the production of external benefits and the avoidance of negative externalities, this type of zoning may not be necessary, as will be clear from the section below on Forest Vocation Lands. 


\section{Ecological-Economic Zoning}

One of the important deficiencies of AEZ is the fact that it does not consider economic factors in the process of analysis. EcologicalEconomic Zoning (EEZ) is a prescriptive model that tries to address this deficiency.

EEZ is a kind of zoning which integrates in zone definitions Agro-ecological zoning elements with socio-economic factors and a wider range of land uses. Besides taking into account all the physical-biotic environment factors used in the AEZ methodology, it also considerers the socio-economic conditions affecting decision making. It is the hope of the proponents of this methodology that, by matching both sets of data through multiple goal analysis, EEZ provides a tool for the various landowners and other stakeholders to arrive at a consensus on the optimal use or non-use of the land to be subsequently executed through legislative, administrative and institutional actions on demarcated spatial units.

EEZ has some of the some difficulties of the AEZ, compound by the use of frequently changing economics conditions and the need to convert its results in inputs of a command and control instrument to assure, finally, the objective of directing the proper use of the land. That implies even more complex methodologies, data, variables, expensive equipment and specialized personnel. While the results of the EEZ depend on the natural characteristics of the site and the crops considered, factors that change less often over time, the essential feature of EEZ is its dynamic character. EEZ needs to be frequently updated to be relevant for decision making under the changing socio-economic conditions in the region of concern and varying outside influences, such as world market trends. These changing economic circumstances can lead to important changes in the conclusions of the EEZ and its usefulness for decision makers.

Annex 1 presents a summary of the basic features of soil and land classifications discussed above.

\section{Soil and land classifications, and the price system}

The decisions about the use land resources depend on a series of factors. Most LAC countries have established a framework where landowners operate, that is based on the exchange mechanism
Table 3: Potentially cultivatable lands covered with forest ecosystem in selected LAC countries.

\begin{tabular}{|c|c|c|c|c|c|}
\hline \multirow{3}{*}{ Country } & \multirow{3}{*}{$\begin{array}{r}\text { Total land } \\
\text { in forest } \\
\text { ecosystems } \\
1,000 \text { ha }\end{array}$} & \multicolumn{4}{|c|}{$\begin{array}{c}\mathrm{VS}+\mathrm{S}+\mathrm{MS} \text { land for wheat, rice and } \\
\text { maize mixed inputs }\end{array}$} \\
\hline & & \multirow{2}{*}{$\begin{array}{r}\text { Total } \\
\text { 1,000 ha }\end{array}$} & \multicolumn{3}{|c|}{ Under forest ecosystems } \\
\hline & & & 1,000 ha & $\begin{array}{r}\% \text { of } \\
\text { forest }\end{array}$ & $\begin{array}{r}\% \text { of } \\
\mathrm{VS}+\mathrm{S}+\mathrm{MS}\end{array}$ \\
\hline Surinam & 12,755 & 4,332 & 3,665 & 28.7 & 84.6 \\
\hline Guyana & 16,500 & 6,065 & 4,282 & 26.0 & 70.6 \\
\hline Peru & 64,484 & 9,221 & 5,113 & 7.9 & 55.4 \\
\hline Bolivia & 41,017 & 53,510 & 27,305 & 66.6 & 51.0 \\
\hline Guatemala & 5,212 & 2,344 & 1,074 & 20.6 & 45.8 \\
\hline Brazil & 399,010 & 288,454 & 125,292 & 31.4 & 43.4 \\
\hline Honduras & 6,000 & 1,880 & 594 & 9.9 & 31.6 \\
\hline Chile & 16,500 & 3,432 & 956 & 5.8 & 27.9 \\
\hline Venezuela & 44,500 & 35,738 & 9,618 & 21.6 & 26.9 \\
\hline Paraguay & 8,320 & 9,637 & 2,417 & 29.1 & 25.1 \\
\hline Mexico & 45,781 & 28,832 & 6,484 & 14.2 & 22.5 \\
\hline Panama & 3,260 & 1,304 & 252 & 7.7 & 19.4 \\
\hline Nicaragua & 3,200 & 3,055 & 577 & 18.0 & 18.9 \\
\hline Costa Rica & 1,570 & 562 & 97 & 6.2 & 17.3 \\
\hline Colombia & 53,000 & 19,171 & 3,105 & 5.9 & 16.2 \\
\hline Bahamas & 93 & 715 & 54 & 58.1 & 7.6 \\
\hline Domin. Rep. & 600 & 607 & 33 & 5.5 & 5.5 \\
\hline Jamaica & 185 & 38 & 1 & 0.6 & 3.2 \\
\hline Argentina & 8,680 & 78,476 & 2,372 & 27.3 & 3.0 \\
\hline Ecuador & 8,184 & 3,684 & 100 & 1.2 & 2.7 \\
\hline El Salvador & 105 & 411 & 7 & 7.1 & 1.8 \\
\hline Haiti & 140 & 299 & 4 & 2.6 & 1.2 \\
\hline Uruguay & 57 & 14,140 & 40 & 70.2 & 0.3 \\
\hline TOTAL & 739,153 & 565,907 & 193,443 & 26.2 & 34.2 \\
\hline
\end{tabular}

Modified by the author from Fischer, van Velthuizen, Shah and others, (2002). Spreadsheet 12 (CD-ROM).

Note: the absolute values represent the extents of lands suitable (S), very suitable (VS), or moderately suitable (MS) for rain-fed wheat, rice, or grain maize (maximizing technology mix) classified as forest ecosystem in the Global Land Cover Characteristics (GLCC) 30 arc-sec database. The data excludes "forest areas (sic), protected areas, and land required for habitation and infrastructure.” P. 99. 
complemented with authoritarian and persuasion instruments (Lindblom, 1977).

The market mechanism is critical for landowners in taking their production decisions about what, where, when, how, with what inputs, how much to produce, as well as for whom to sell. This exchange mechanism is sustained on voluntary transactions guided by price signals and the profit motivation; and based on the principle of freedom, an increasingly recognized critical core element for the development of nations (Sen, 1999). When working properly, markets can conduce to efficient results not only for the individual landowners but also for society.

However, several factors can limit the efficiency that the market system can generate in achieving the efficient use of land resources. One of the difficulties for a proper role of prices is the lack of adequate information about 1) the nature and limitations of land resources, 2) the technologies available for production, and prices and other price-determining factors. Soil and land classifications help in various degrees, the provision of information for the landowners' decision making. Therefore, these classifications can be an important support to improve the quality of the decision making, price formation, and the market functioning.

As discussed above, information also has a cost, and in the case of the most complex and sophisticated land classification methodologies, they can be substantial and almost unfeasible for the average developing country. Therefore, it is an important challenge to identify the most efficient kind and degree of information that is affordable by a given country but can best support landowners' decision making. Information that has a price can be obtained from the market place. However, some of this information is considered public goods, therefore, a market failure whose adequate supply requires special mechanisms, often dependent on public funds to be provided.

For several reasons, including the existence of externalities, some of these methodologies seek not to ultimately support market based decision making, but rather, they try to serve as a basis for the authoritarian determination of land uses by imposing on landowners what is thought to be the best or most desirable uses for the land. The advantages and disadvantages of the use of command and control instruments has been extensively discussed in the literature and does not need to be repeated here which would go beyond the purposes of this paper. Here it suffices to notice that these authoritarian solutions have rarely been successful in determining efficient land uses in developing countries, while market based instruments have generally been more favored.

Therefore, it seems that the most recommendable role for cost effective soil and land classifications is that of generation of better information in support of market based decision processes. They also allow an understanding of the factors and conditions determining S\&WRE, as well as help in the formulation of a framework for the design of public policies addressing them.

\section{Forest Vocation Lands}

The concept of Forest Vocation Land (FVL) is often used in LAC forest legislation, thought some times under different names, specific definition criteria, or roles in the forest legal framework (see Annex 2). Unlike the above classifications which identify the site situations for which agriculture uses can be undertaken without major negative environmental impacts, given the site's soil, topography, and climate characteristics and agriculture crop requirements; FVL are site situations for which the land cover should be forest. In some LAC legislations, the forest cover is mandatory, while in other cases it is preferential.

The classification of land according to its vocation is a prescriptive model that identifies the preferable general type of land cover that a given land area should have to assure that no soil or water related externalities occurs. It takes in consideration the site's basic physical characteristics of soil and 
topography (and sometimes rainfall, if relevant) which generally are not changeable over short time periods. It assumes that no exceptional investments are made to effectively conserve water or soil resources, and, therefore, prevent the occurrence of related negative externalities and on-site fertility losses. Land vocation classification does not depend on the current land cover or use (see box 5).

Despite the extensive application by LAC legislators of the FVL concept, the discussions about it in the forest policy literature are surprisingly few. The extensive use of the concept in forest legislation may be related to its intuitive nature, the easiness of identification by landowners and law enforcers, and its expected cost effectiveness to comply with or enforce. This paper also tries to contribute to fill this gap.

\section{Box 5: Forest Vocation Land defined.}

Forest Vocation Lands are those that, due to their physical site features such as soil, topography, and the rainfall it receives, should be kept under forest cover or other sustainable land use if soil or water related negative externalities are to be avoided. FVL classification does not depend on the type of cover the land actually has, nor does it depend on the requirements it may have for agriculture crop or forest production. Therefore, lands with no forest cover or use can still be classified as FVL if their physical features so indicate; while lands covered with forest may not be FVL.

For the purpose of this paper, and indeed for the design of forest policies concerned with forest based externalities, it is sufficient to classify land in three basic types: agriculture, and forest vocation lands; and other lands. In some occasions in this paper, agriculture vocation lands and other lands (areas whose eventual uses are unlikely to be rainfed agriculture or forest such as deserts, drylands, or settlement areas) will be referred as non-forest vocation lands (nFVL).

The variables considered in the identification of FVL are principally topography (slope gradient and length), and soil erodibility, and, less often and only if relevant, rainfall. They are the same site specific natural climate and physical factors discussed above as affecting erosion rate and which are not easily or cheaply changed by landowners.

The specific FVL definition found in forest legislations vary from country to country, and they are often more complex than actually necessary (see annex 3). However, the theory allows much simpler and pragmatic definitions. FAO (2000) provides data and criteria for an example of how FVL can be defined in pragmatic terms. In this case, TVF is defined as those lands with slopes greater than $30 \%$, and areas between 8-30\% with erosion prone soils, which are not deserts, drylands, water surface, or settled areas. Landscapes with slopes less than $8 \%$ are classified as agriculture vocation lands (AVL) because they would not require any additional investment to avoid soil or water related externalities. Annex 4 presents an estimation of FVL for selected LAC countries.

As land cover has no relevance for the classification, a land can be classified as FVL even if it has no forest cover, or has agriculture or cattle ranching use. Conversely, lands which have a forest cover do not need to be forest vocation lands.

On the other hand, AVL can be much more flexible because they are less likely to generate water or soil related externalities, regardless of their actual use or cover. They can sustain any level of use intensity from different land uses, with much smaller soil erosion and water risks. Therefore, AVL can be used for agriculture or forest uses or covered with forest without generating on-site or off-site adverse impacts. AVL, as a consequence, are of no concern to forest policies designed to address negative S\&WRE.

FVL require special attention from society because, unlike AVL, their misuse may generate negative S\&WRE. To avoid these adverse by-products, FVL should have a forest cover, regardless of whether it is a natural primary or secondary forests, a tree plantation, or any other cover that can be classified as forest (see box 2). They can also be used for agriculture or cattle ranching if, and only if, the landowner can adopt effective soil and water conservation measures to avoid such externalities. Other uses equally protective are also acceptable. 
FVL, as described here, have only incidental benefits for biodiversity conservation since there is not a requirement that they need to be covered with natural forests. This requirement is not necessary because FVL are mainly concerned with the prevention of S\&WRE.

FVL without forest cover or equivalent protection continues to generate negative S\&WRE detrimental to social welfare. Therefore, any government policy directed at improving social welfare related to degrading FVL, must adopt measures that stop such deterioration by (re)establishing some effective protective cover or use. As mentioned before, landowners have a range of alternatives to accomplish that, by choosing and paying for the one that best fits their objectives and means. A policy that has this type of result at the landowner's cost, 1) assumes that landowners have no right to generate these externalities, 2) is compatible with Polluter-Pays Principle (PPP), and 3) does not generate a further burden, a fiscal cost, to society (see box 6).
Box 6: Polluter Pay Principle defined.

"The 1972 OECD Council guiding principles state that 'the principle to be used for allocating costs of pollution prevention and control measures to encourage rational use of scarce environmental resources and to avoid distortions in international trade and investment is the PPP. The principle means that the polluter should bear expenses for carrying out the above mentioned measures decided by public authorities to ensure that the environment is in an acceptable state. In other words, the cost of these measures should be reflected in the cost of goods and services, which cause pollution in production and/or consumption. Such measures should not be accompanied by subsidies that would create significant distortions in international trade and investment"' (OECD, 2001: 45)

\section{FVL and economic efficiency}

The basic requirement for the proper use of FVL is that they should be covered by forests or be used in such a way as not to generate soil erosion and water conservation related negative externalities for society. When this requirement becomes law, landowners have their land use options for FVL limited to those which will not generate such externalities. By only being allowed to use FVL with uses which effectively conserve soil and water, landowners are actually internalizing these externalities in their decision making and complying with the PPP whenever investments in protective measures are required.

This requirement in fact is restricting the landowners' property rights by limiting their freedom to choose land uses that can generate negative S\&WRE. Sometimes, such restrictions are legally based on the property rights conditionality established by the so called social function of the land. Put differently, in many countries, society has the right not to suffer the negative consequences of S\&WRE that may result from the misuse of FVL by their owners. For further discussion on the importance of the distribution of property rights between landowner and society, see OECD (2001).

The reduction of alternative land uses imposed by the requirement for sustainable use of FVL is relatively small because it does allow for the selection from a wide range of land uses that do comply with it. For instance, any forest cover type is sufficient for compliance, while agriculture or grazing uses, or in fact any other use like roads, buildings, etc, are acceptable provided effective soil and water conservation measures are adopted. Therefore, landowners have at their discretion a flexible range of alternatives to choose from. This flexibility should reduce the eventual private opportunity costs that they may have to give up to comply with the requirement.

Since it is assumed that society has the right to be free from negative S\&WRE regardless of the location where they occur, FVL based policies do not discriminate between these externalities occurring in watersheds of greater importance for society or not. Therefore, externalities occurring in a watershed important for production of hydroelectricity, potable water, or irrigation, would have the same legal basis for state action. The policy, therefore, is based on a matter of a legal right, which by definition does not distinguish special areas where such rights are more or less important to be respected. Nevertheless, it is 
expected that the state can strategically pay more attention to priority watersheds by allocation additional resources to enforce FVL based forest policies in them.

Government costs for the implementation of a FVL based policy are relatively small. There are two basic types of costs involved: FVL identification costs, and enforcement costs. There is an initial one-time cost to identify only the forest vocation lands located outside officially created protected areas. This is so because protected areas are under a separate regimen of use and nFVL do not need to be identified because they are of no concern for soil and water conservation issues. Depending on how FVL are defined, the first task in identifying FVL in the field would be to map the landscapes with slopes greater than 30\% and those between 8\% and 30\% (See annex 2 for an estimation for selected LAC countries). Slope gradient can be identified through remote sensing at relatively low cost. One can usually classify safely the first set (slopes greater than 30\%) as FVL. Areas with slopes between $8 \%$ and $30 \%$ can be matched with soil erodibility maps to identify those that are at risk for soil erosion. If rainfall varies substantially within the country's borders, this factor can be added to help to identify the FVL in this second set. Otherwise, a simple rule of thumb may be devised to limit the decision to soil erodibility and slope gradient. The specific methods to undertake these tasks are well known, since they are a subset of methods used in other soil classifications, as described above.

Enforcement costs are also relatively smaller. There are many scenarios that one can describe to enforce the requirement of forest cover on FVL. Law enforcement costs are expected to be relatively small because the lack of forest cover resulting from the misuse of FVL is relatively simple to detect by remote sensors and on the ground. Law enforcers can be easily directed by remote screening to FVL without forest cover to verify whether current use generates S\&WRE. Therefore, enforcers need to be concerned only with FVL without a forest cover, not having to expend resources of time with nFVL, regardless of their use or cover.

The following section discusses further the efficiency consequences from the requirements of forest cover for FVL. 


\section{Land Rent and Forest Vocation Land}

Land rent is a model that helps to explain the economic consequences related to production in lands with varying degrees of quality; the land use decision making; the forest vocation land classification; and the S\&WRE of different land vocation, cover, and use scenarios (Barlowe, 1978).

For the purpose of this paper, the model is also important because it helps to explain some economic issues related to forest vocation lands. It can explain, for instance, when landowners may find it to their advantage to assign a forest use to land, the consequences of additional costs associated with the adoption of soil and water conservation measures in agriculture uses, the consequences of externalities not being considered by the landowner; what happens to land use choice if environmental payments are made for forest use of land, and the impact of subsidies and other policies that privilege agriculture uses in detriment of forest uses.

As land quality decreases, land productivity decreases and average and marginal costs of production increase. This is so because landowners will have to invest more in soil preparation, conservation, and fertilization while even with these additional costs, productivity will tend to decrease. Best quality agricultural lands such as those shown as class I in Table 2, will require much less investments and will yield greater production than other lands with worse quality. In a perfect competition microeconomic model assuming lands at the same access costs to markets, when output price allow worse quality lands to be called into production, the best quality lands will generate the greatest land rent because landowners will sell their outputs for a price that more than cover their average cost. Landowners can continue using decreasing quality lands, until their average costs for these lands equal the output price (and equals marginal costs). At this point, landowners of those marginal lands will make normal economic profit, but no economic rent. Landowners will not use lands of worse qualities because that would reduce their profits as they would spend more money to produce the next unit of output than the price they could sell it for.

Land rent is that surplus profit that better quality landowners get as compared to marginal lands that make only normal economic profit. Box 7 presents alternative

Box 7: Land rent defined.

Land rent is the economic rent of land as a factor of production.

Economic rent is the proportion of the earnings of a factor of production that exceeds the minimum amount necessary to induce that factor to be supplied. William Blinder and Baumol, 2005: 404

Rent on any piece of land will equal the difference between the cost of production the output on that land and the cost of production it on marginal land. William Blinder and Baumol, 2005: 405.

ways to define the same concept.

\section{Land rent and the choice of land use}

For any quality of land, landowners would prefer the use that would yield the greatest profit, or the greatest land rent. Therefore, for them to use land for forest production, it would be necessary for the forest use to yield the greatest land rent as compared to alternative land uses. Although not necessary, it is often the case that lands in rural areas with best quality will generate the greatest rent when used for agriculture production. On the other hand, forest uses will be more competitive in lands of lesser quality. The land rents that forest or agriculture land uses can command for different land qualities are illustrated in figure 5. 
Figure 5: Land rent for agriculture and forest uses for different land quality levels Modified from Barlowe, 1978.

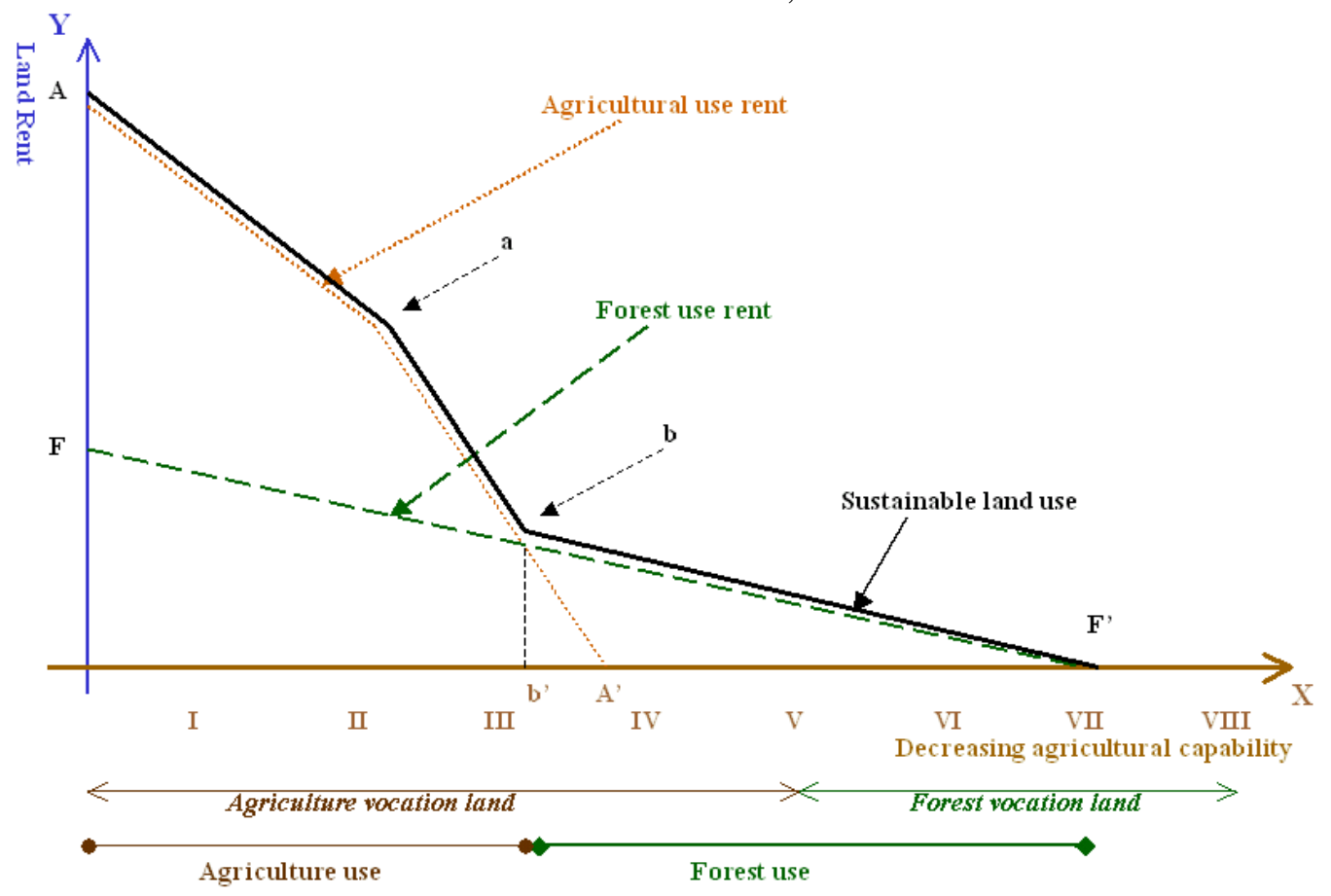

In this figure, land rent is plotted on the $\mathrm{Y}$ axis while the $\mathrm{X}$ axis represents continuously decreasing land capability from class I to class VIII in areas of equal market accessibility. Doted line AaA' represents the land rent level that agricultural uses (including here not only crops but also cattle ranching) can obtain as land quality decreases. Point "a" on this line represents the point where landowners would have to apply additional and increasing soil and water conservation measures if no related negative externalities were to reduce local social welfare as they use lands more prone to erosion. This is equivalent to negative S\&WRE being fully internalized and considered by landowners in their decision making, i.e., a full application of the PPP by these producers. Point A shows the greatest level of land rent that agricultural use can provide in the best quality lands, while point $A^{\prime}$ is the land quality for which agricultural use becomes marginal as it yields no rent and only a normal profit level.

Dashed line FF' represents the land rent that forest uses can obtain. Like agricultural use, forest use also decreases as land quality decreases up to land quality F' where forest use would yield no land rent and would only obtain normal profit. Land qualities worse than that found in point F' would be unprofitable even for forest use, and would likely have only a forest cover.

Solid line AabF' represents the land use combination for which landowners would, for each land quality, maximize land rent and profits without generating soil or water related negative externalities, i.e., the most profitable sustainable land use. Point $\mathrm{b}$ is called margin of transference from agricultural use to forest use because at this land quality level, it would be more profitable for landowners to use land for forest production than for agriculture, although this latter use could still be profitable. Lands qualities from b' to A' are said to be in a zone of transference between forest and agriculture uses. Lands of better quality than b', though they may be used in forestry, are socially and privately better off if used for agriculture production. On the other hand, land qualities worse than b' are better used for forest use though they could be used profitably for agriculture until land quality A' (Barlowe, 1978; see also van Kooten and Folmer, 2004). 
Figure 5 helps to clarify the vocation land classification presented above. Even thought vocation land classification varies with the quality of the land, it is independent of the land rent it can yield or the land use or cover on a given plot. Forest vocation lands in this example, are defined as those in land quality categories $\mathrm{V}$ and worse. The model stresses the fact that forest vocation land may be used for different uses including agriculture, if the proper soil and water protective measures are adopted on a profitable basis. Conversely, agriculture vocation land may be used for forest production or cover, depending on the specific land rent that these different uses can command on a specific site at a given time. In this example, lands with qualities inferior to A' should be used for forest use or cover if no water or soil related negative externalities are to affect adversely society; i.e., forest use should prevail from quality A' till F', while forests should cover worse quality lands.

It should be noted that land quality does not progress as uniformly as assumed in this figure and that it is not unusual that large pieces of land are dominated by one or few land quality classes. Therefore, it is possible to find properties whose lands are dominated by agriculture vocation lands while others are forest vocation lands. If soil and water conservation measures are adopted by landowners whenever necessary, both of these land vocation classes would yield private and socially best results, though at different levels.

The model is also useful to explain the concept of opportunity cost of a given land use, even in a case as simple as the one illustrated above. For instance, the most profitable land use alternative for land class I is forest use, while agriculture use is the best alternative for land qualities between b'A'. The net income that landowners loose for not applying these best

Box 8: Opportunity cost defined. The opportunity cost of any decision is the value of the next best alternative that the decision forces the decision maker to forgo. Blinder and Baumol, 2005: 39. alternative land uses is their opportunity cost (see also box 8). This simple and yet powerful concept is very useful to identify the potential losses of landowners when a forest policy requires the adoption of a less profitable land use so that a given externality may be produced. Note, however, that lands of worse quality than A' have no opportunity cost because there is no profitable alternative use for those lands. In the case that forest use is not possible for other reasons, the land would be left unused but with a forest cover.

Another important use of the land rent model is to explain the impact that distance from the market have on the rent that a given piece of land can command. Distance from the market, in this case, is another quality feature of land for which the model can be applied instead of land production quality. This could be done by changing the $\mathrm{X}$ axis variable in figure 5 for distance and fixing land production quality. Thus, land of the same production quality that is closer to a market would generate higher rent from a given use because the cost of transportation of inputs or outputs would be smaller. In this case, it is common to analyze the role of urbanization on land use in lands closer to markets, but this would go beyond the purpose of this paper (see van Kooten and Folmer, 2004). It is useful to note, however, that an increase of transportation cost could be represented in figure 5 by a shift to the left of lines AaA' and FF'. That means that lands further away from markets would have forest use, forest cover, or no use. Conversely, a new road coming to inaccessible areas would dramatically change land rent as a consequence of reduced transportation costs and increase agriculture or forest uses. 


\section{Social desirability of land use, cover, and vocation scenarios}

The land rent model is useful to examine the consequences of different combinations of land vocation, forest cover, and land use in regard to the production of undesirable S\&WRE. This discussion is important because forest policy would need to concentrate on addressing only the possible scenarios where these externalities can be found.

Table 4 summarizes the possible scenarios by identifying situations where agriculture or forest uses may be desirable, indifferent, or undesirable from society's standpoint. All of these scenarios are possible considering the different land rent yield from a given site.

First, note that all scenarios where there is forest cover are either desirable or indifferent (columns A and C). This is because of the protective role of forests in areas of forest vocation lands and the fact that agriculture vocation lands, as defined here, are not at risk of erosion. A forest cover of a piece of land, therefore, means that there is little or no negative S\&WRE affecting society. Likewise, lands with forest use (line 1) are either desirable or indifferent for similar reasons. A scenario such as AVL with forest use, can be found in land qualities between b'A' in figure 5. If forest use can generate more land rent as a consequence of a shift to the right of line $\mathrm{FF}$, the AVL that could have forest use would increase. It is also relevant to mention that areas under forest use may become out of forest cover temporarily just after intensive forest harvesting (B1

Table 4: Land use, cover, and vocation and the social desirability of possible scenarios.*

\begin{tabular}{|c|c|c|c|c|}
\hline \multirow{3}{*}{$\begin{array}{c}\text { Forest cover } \\
\text { Forest } \\
\text { use (1) }\end{array}$} & \multicolumn{2}{|c|}{$\begin{array}{c}\text { Forest vocation } \\
\text { land }\end{array}$} & \multicolumn{2}{|c|}{$\begin{array}{c}\text { Agriculture vocation } \\
\text { land }\end{array}$} \\
\hline & Yes (A) & No (B) & Yes (C) & No (D) \\
\hline & Desirable & Desirable & Indifferent & $\begin{array}{l}\text { Np or } \\
\text { indifferent }\end{array}$ \\
\hline $\begin{array}{c}\text { No forest } \\
\text { use }^{1}(2)\end{array}$ & Desirable & $\begin{array}{l}\text { Undesirable } \\
\text { or } \\
\text { Desirable }\end{array}$ & Indifferent $^{6}$ & Indifferent \\
\hline $\begin{array}{c}\text { Sustainable } \\
\text { agricultural use (3) }\end{array}$ & Desirable & Desirable & Indiferent $^{2}$ & Indifferent \\
\hline $\begin{array}{l}\text { Unsustainable }^{4} \\
\text { agricultural use (4) }\end{array}$ & $\mathrm{Np}$ & Undesirable & Np & $\mathrm{Np}$ \\
\hline
\end{tabular}

* Scenarios are undesirable (desirable) when (no) adverse soil or water related externalities are generated by the land use, and indifferent if land use has no influence on these externalities.

1- Excludes agricultural use.

2- Desirable for society because this scenario implies an agroforestry use, which usually conserves soil and water.

3- This situation arises when the land is under a period of transition as when wood has just been harvested and a new forest is beginning to be formed. The temporary nature of this situation combined with temporary soil and water conservation measures whenever needed, is desirable for society. In the case of agriculture vocation land, there is no need to adopt temporary these conservation measures.

4- Refers to agricultural use that generates negative soil or water related externalities.

5- Desirable only if the land is under a sustainable land use.

6- Although this scenario is indifferent as far as the criteria of desirability used here, it may be undesirable for the landowner and for society if the accessible land resource is not being used to its greatest social land rent. However, it does not generate negative externalities.

Np. Not possible.

and D1). Provided temporary soil and conservation measures are adopted during the exploitation period and land returns to forest use, the associated negative externalities may be minimal.

Thus, forest vocation lands covered by forests (column A) can be used properly for forest use (except for lands of extremely low quality), or for sustainable agriculture uses in the form of agroforestry. They can also be left just as forest cover and generate no land rent, but would still be desirable for society since they will protect soil and water besides producing other possible externalities. This scenario could be found if the line AabF' in figure 5, for instance, were shifted to the left and, therefore, increased the land quality classes that would be to the right of point $F^{\prime}$, the forest use margin region. 
In the case of agriculture vocation lands (columns $C$ and $D$ ), All their scenarios are indifferent to the use or cover of these lands, because AVL have been defined as arable lands that have small risk of soil erosion and water conservation externalities with any type of normal use.

Likewise, all sustainable agriculture uses of land (line 3), including in FVL, are either indifferent or desirable. The social desirability found for these scenarios is similar to any other use, urban or otherwise, that can be given to FVL but that adopts measures that will prevent any soil or water related negative externalities whenever necessary.

Therefore, there are really only two basic scenarios that are of concern for forest policy: the case where FVL are being used for unsustainable agriculture use or the case where they have no forest cover or use ${ }^{5}$.

The unsustainable agriculture use of FVL can be profitable to landowners only if they do not adopt soil and water conservation measures. Conversely, this use would generate no land rent or be unprofitable, but in both cases produce no social costs if negative externalities were internalized. However, this is not usually the case and the continuous unsustainable agriculture use of FVL is the most damaging scenario for society and the principal concern for forest policy of the second group.

\section{Good and $\mathrm{bad}^{6}$ deforestation}

Deforestation is a temporary activity. If the deforested area is not inside an effective preservation unit established to protect genetic resources in situ (in which case deforestation is definitely bad), the real importance of deforestation depends on factors such as the use that the land will have afterwards (van Kooten and Folmer, 2004), its vocation, and the greatest land rent that the land can yield. To understand when deforestation may be good or bad, one must analyze the scenarios made up by possible combinations of such factors.
Table 5: Good or bad deforestation depends on land vocation, and on the land use given to the site afterwards and its respective rent.*

\begin{tabular}{|c|c|c|c|c|}
\hline \multirow[b]{2}{*}{$\begin{array}{l}\text { Greatest land } \\
\text { use rent got by }\end{array}$} & \multicolumn{2}{|c|}{$\begin{array}{l}\text { Forest vocation } \\
\text { land }\end{array}$} & \multicolumn{2}{|c|}{$\begin{array}{c}\text { Agriculture vocation } \\
\text { land }\end{array}$} \\
\hline & $\begin{array}{l}\text { Forest use } \\
\text { (H) }\end{array}$ & $\begin{array}{l}\text { Ag. use } \\
\text { (I) }\end{array}$ & $\begin{array}{l}\text { Forest use } \\
\text { (J) }\end{array}$ & $\begin{array}{l}\text { Ag. use } \\
\text { (K) }\end{array}$ \\
\hline $\begin{array}{l}\text { Forest } \\
\text { use (1) }\end{array}$ & Good & Bad & Good & Bad \\
\hline $\begin{array}{c}\text { Forest } \\
\text { cover }(2)\end{array}$ & Bad & Bad & Bad & Bad \\
\hline $\begin{array}{c}\text { Sustainable } \\
\text { agricultural use (3) }\end{array}$ & Bad & Good & Bad & Good \\
\hline $\begin{array}{c}\text { Unsustainable } \\
\text { agricultural use (4) }\end{array}$ & Bad & Bad & Bad & Bad \\
\hline
\end{tabular}

To understand these scenarios, it is necessary first to expand the definition of the concept of desirable and undesirable used in table 4 so as to include land rent and thereby be able to differentiate when deforestation may be good or bad. Thus, good deforestation refers to the maximization of land rent at same time that negative S\&WRE are not present. Bad deforestation means that either land rent is not being maximized or that soil and water related externalities are affecting adversely society, or both (Gregersen, Belcher, and Spears (1994) have called them productive and unproductive deforestation).

\footnotetext{
${ }^{5}$ If the latter case is temporary and there is a chance that a secondary forest cover may be formed by the area just being abandoned with no use by the landowner, the externalities will also be temporary (this is the case of fallow areas in slash and burn production systems).

${ }^{6}$ The use of such value loaded words was purposely chosen to intrigue, and stimulate reflection and discussion about the related issues.
} 
Table 5 summarizes the possible scenarios given the above definition and the starting assumption that the land under consideration is, of course, covered with natural forest.

An examination of the results found in table 5 indicates that most deforestation scenarios can be classified as bad. However, there are 4 cases in which deforestation can be good for society and for landowners. To summarize, deforestation is good in the instances where the new land use generates the greatest land rent and is sustainable, i.e., does not generate S\&WRE. This happens when a natural forest covering a forest vocation land is deforested but the land is latter used for forest use when it is the one that generates the greatest land rent (scenarios H1 and J1), or the land is used for sustainable agriculture when this land use generates the greatest land rent (scenarios I3 and K3).

Good deforestation scenario H1 represents situations where the natural forest cover on forest vocation lands is more intensively managed as secondary forest or converted to a forest plantation, either with native or introduced species, whichever generates the greatest land rent. Scenario J1 is similar, except that the vocation of the land is for agriculture use, although this use does not generate a greater rent than the forest uses mentioned. This latter case can happen, for instance, in situations where the land is inside the economic radius of a forest industry and far enough from agriculture consumption centers.

Scenario I3 is the case of a natural forest on forest vocation land which is converted to a sustainable agriculture use, i.e., an agriculture use that includes all measures to prevent soil or water related externalities. This can happen in areas that are located sufficiently close to agriculture consumption markets that make the agricultural use of FVL to generate enough rent to be able to compete with other agriculture vocation lands in production in more distant areas. Proximity to markets allows these landowners to be able to invest in soil and water conservation measures and still be competitive.

Scenario K3, on the other hand, is agriculture vocation lands covered with natural forests whose distance to market and transportation costs allow them to be used for agriculture use, thereby obtaining a positive land rent. Table 3 above estimated, for selected LAC country, a total of 193 million ha of lands that are cultivatable and are covered by natural forest ecosystems. As roads and other transportation infrastructure are established or improved, the costs of bringing these lands into production diminish and they will tend to be converted to agriculture use without generating negative externalities for society. Other lands under the conditions of scenario K3 but are inaccessible will continue under natural forest cover or will be used for forest production.

Not to deforest in these four scenarios means that society and landowners are paying an important opportunity cost, since the sustainable land use will not collect the rent that they can produce.

Conversely, all the scenarios where bad deforestation is found are so because forest covered land is being converted to a lesser profitable or unsustainable land use. Special cases of this general conclusion are found when the new land uses do not generate any rent, in which case deforestation will be bad too.

\section{Relaxing some assumptions}

The land rent model is also useful in the case one relaxes some assumptions to explore other situations frequently found in the real world. For instance, what would happen if landowners do not adopt soil and water conservation measures? It is very common that landowners do not adopt these conservation measures because the costs that this misuse generates are external to their decision making process. They behave as if they had the right to generate the negative S\&WRE. This situation could be shown with this model by separating private land rent from the social land rent, the latter of which was shown in figure 5. In this case, landowners would have smaller average private costs which would yield bigger private land rent from the use of each land quality, at least in the short run. This could be represented in figure 5 by a 
parallel line shifted to the right of line AaA'. When landowners do not adopt soil and water conservation measures, they are using their land more intensely, and agriculture use advances over poorer quality lands that should be under forest use, and generate further negative water and soil related externalities.

The situation just described could be aggravated if, on top of not conserving soil and water, unsustainable agriculture land use is subsidized by government policies leading private land rent line to be further shifted to the right. This is in fact a very common scenario that has led to the misallocation of forest vocation lands to agriculture use.

If the price of agriculture commodities increases (decreases), one should expect a shift to the right (left) of the AaA' line leading to an increased (decreased) use of forest vocation lands for the production of such commodities. In the situation that results in the increase in the use of FVL for the production of more valuable agriculture crops is accompanied with the additional measures to protect soil and water in these more soil erosion prone areas, there would be no adverse consequences for society. However, as mentioned above, these scenarios, though possible, are not found often because of lack of internalization using the PPP that would lead landowners to adopt and pay for such protective measures. If the price increase is the result of a government intervention that distorted the market price, the bad deforestation that can result would actually be promoted by the state.

The model is also useful to show what would happen if government decides to pay for some of the positive externalities that forest cover or use generate, internalizing these benefits into the decision making of landowners. For instance, if forest cover receives a payment proportional to the rate of carbon capture or stock stored in forests (for emission avoidance, e.g.), this payment would increase the land rent of forest use or cover. This land rent increase can be represented by a shift to the right of line FF'. This would also lead to better quality lands at the margin of transference to be switched to forest use or cover.

It should also be mentioned that other lands uses not represented here can be applied to forest vocation lands without generating adverse social consequences related to soil and water conservation. For instance, well designed and executed urban developments can be socially desirable in very well located FVL and yield sustainable land rent for their owners without affecting adversely society. Although there are increased risks associated with urban occupation of those lands, the greater private land rent this use can command may be sufficient to finance the protective measures. However, one can find too many examples where no such measures are adopted, as in the case of spontaneous and unregulated urban use frequently found in developing countries. Hence, only a case by case evaluation will be able to tell that a non forest cover or use of FVL is socially acceptable because soil and water conservation measures have been adopted.

\section{Land rent and biodiversity preservation}

The land rent model is also useful to improve understanding about the costs and benefits associated with the preservation of land for the purpose of in situ preservation of genetic resources. 
The use of land to preserve genetic resources can be easily represented in figure 5 by just adding a horizontal line crossing the Land Rent axis above point $A$, as shown in figure 6 . This line represents the rent that society attributes to these lands, regardless of their quality, for the purpose of assuring the preservation of genetic resources that exists therein. This preservation rent for society should be greater than any other use that landowners can assign for society to justify the allocation of these lands to this use. Note that the rent concept is net of all costs necessary and sufficient to assure the production of the land use. Therefore, the preservation cost should include costs such as

\section{Figure 6: Social land rent of genetic resources preservation use must be greater than all other land use costs.}

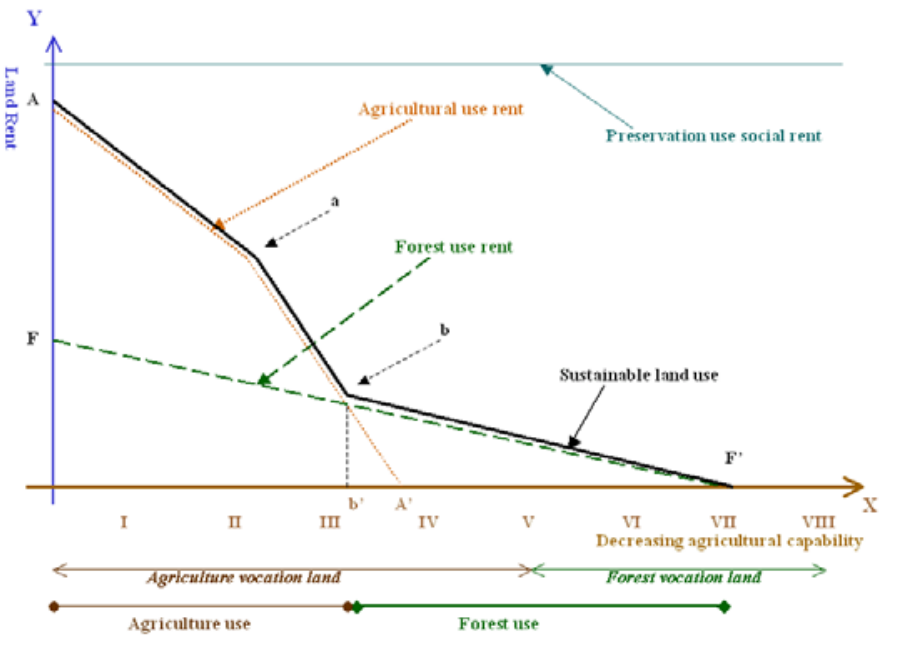
administrative costs (personnel, equipment, materials), infrastructure (service roads, buildings, etc.), the cost of assuring control over land use decision making, as well as the opportunity cost of landowners.

The model helps to understand that when society defines a piece of land as a preservation unit, landowners will bare the opportunity costs of not being able to use the land for its most profitable alternative use. If this cost is not compensated, society (local and global) will be benefiting from the preservation of the genetic resources while landowners will be baring the opportunity cost. If not compensated, this distribution issue leads landowners to be less willing to cooperate.

The compensation that society must be willing to pay, should be sufficient to cover the landowners opportunity cost for each land quality involved. Therefore, lands of better quality that could generate greater rent should receive greater compensation than lands of poorer quality which yield smaller rent. Lands with no rent such as those of worse quality than the forest margin (point F' in figure 5) would not need any compensation because its use would generate a negative rent for landowners, i.e., they would spend more than receive and would not use the land anyhow. There are many forms of compensation for the opportunity cost, such as government expropriation, renting, and easement contracts. In all cases, landowners should be fully compensated for their opportunity cost so that society would get their full cooperation.

In the case of land in a buffer zone around a preservation unit, society should be prepared to pay for the opportunity cost of land uses incompatible with this status if full cooperation from the affected landowners is desired. For instance, if forest cover is consistent with the buffer zone restrictions, no compensation would be needed for lands of quality inferior to b' in figure 5. Land quality worse than b's would be used by landowners for forest use regardless of the existence of the preservation unit, and therefore merit no additional payment to assure such decision. If agriculture use is incompatible with the protection required in a buffer zone, better lands than b', would require compensation of the difference between the land rent that landowners would get from agriculture production and the rent that they are allowed to get from forest use, i.e., the area AabF in figure 5. Because buffer zones allow landowners to choose compatible land uses such as forest use, the compensation needed is smaller than in preservation units where no use is allowed. 


\section{Forest Policy Based on Forest Vocation Land}

This section builds upon the discussions from all previous sections to consolidate a proposal for a forest policy based on the forest vocation land concept, and to present some of its implications. It presents the policy framework with a description of its basic features; the arguments justifying the claim that this policy is simpler and less expensive than comparable policies; the conditions necessary for the successful implementation of the policy; some key operational aspects of its adoption; and discusses its implications for other common fore st policy issues.

\section{The Framework}

The principal directive of a forest policy of the second group--those concerned with the proper provision of forest related externalities-that is based on the concept of FVL is that they should be covered by forests or used with a sustainable land use if no negative S\&WRE are to reduce social welfare.

This directive assumes that landowners have no right to generate soil and water related negative externalities out of their properties, or conversely, that society has the right to an environment without these externalities. The policy assumes this limitation to land

\section{Box 9: Forest policy} directive.

Forest vocation lands should be covered by forests or used with a sustainable land use if no soil and water related negative externalities are to reduce social welfare. Non compliance would be penalized by the state through charges sufficient to stimulate the desirable change. property rights so that, in fact, it results in the internalization of these externalities in the landowners' decision making. Because it is part of the responsibilities of landowners to adopt and pay for the measures that make sure that their use of the land does not affect adversely social welfare, this directive can be considered an application of the Polluter-Pay Principle. Landowners must pay the cost of adopting such measures because they avoid negative externalities. Since there are no net positive welfare gains to society, under this assumption there is no motive for it to support such adoption with direct payments.

Non compliance with the directive would require government action to sanction the land misuse with a charge that would make the adoption of an acceptable land use more attractive. Landowners would choose a land use that result in a forest cover or another sustainable alternative if the land rent of such new use is greater than the one produced by the negative externality-generating one less the value of the penalty charged. The risk of being charged periodically at these effective levels for the continuous misuse of land would provide the incentive for landowners to adopt acceptable land uses. If no rent can be obtained by a productive land use, landowners can always decide to return the land to a secondary forest cover by allowing natural regeneration to take over.

Note that it does not matter when land was converted to the negative externality generating land use. As long as the land is being misused and continues to produce such externalities, government is justified in applying the charges. Both newly deforested areas that are found to be of the bad kind (see table 5) or older converted areas being misused must be subject to the penalties.

This directive addresses one group of forest related externalities, the S\&WRE, and may have indirect benefits for other types of externalities. As more landowners opt for land uses with forest cover, more carbon is expected to be sequestered and stored in the biomass. Biodiversity may increase in some areas kept or returned to some form of natural secondary (or even primary) forest cover , but that would be only circumstantial and not a result by design. 
Because of their special characteristics, as discussed above, addressing carbon sequestration and stock or biodiversity related externalities of forests would require complementary policies that will only briefly discussed here.

\section{Simpler and less costly}

There are four basic features of this policy directive that make it also simpler and less costly to apply than most other forest policies currently in force in LAC countries. First, it requires only that forest vocation lands be covered with forests of any kind. If they are not covered with forests, landowners should be able to demonstrate that their current land use is not generating soil or water related negative externalities, or may be doing so temporarily while a new acceptable land use gets established. These simple requirements give landowners substantial freedom to choose the land use solution that best fits their circumstances so that compliance and opportunity costs will tend to be less than other policy solutions that require a specific land use or technology to be applied. As further discussed below, the policy is also simple to enforce since forest cover can be detected remotely and requires minimum in situ inspections to collect evidences and only for those sites suspected of wrongdoing. This is the basic enforcing necessary to apply a FVL based forest policy.

Second, the policy says nothing about non-forest vocation lands. As discussed above, these lands usually are not at risk of soil erosion or water associated negative externalities. Therefore, agriculture vocation, non-rural, arid or dry lands are all of no concern for this forest policy. The FVL based forest policy neither needs to be monitored nor enforced in those areas which make these activities more focused and less costly.

Third, the policy is only concerned with the way FVL are covered or used on the field (or forest) itself. It has no need to address situations related to how or when forests are being cut, wood transported or marketed; neither is it concerned with the inputs used for forest production. These are frequent controls imposed by many forest norms on forest related entrepreneurs, constraining their freedom to act, leading them to risk the consequences of operating illegally, requiring important government investments in enforcement, and generating discretionary and corruptive situations.

Fourth, because the policy is based on a set of principles and physical conditions that are not changeable easily over time, its usefulness is more resilient to changes in technology and market conditions. Prices of productive inputs or forest products may change, technology may create new ways to use FVL, but these changes will not affect the way the policy is applied, and therefore, does not require additional resources or legal adjustments to adapt to these changes.

These characteristics make government intervention much simpler, less costly, and less discretional, freeing fiscal resources to improve enforcement or to facilitate the provision of supporting services to promote the growth of sustainable forest businesses or other more desirable social investment.

\section{Conditions for successful implementation}

The successful implementation of a FVL based forest policy depends on the existence of a few but critical necessary conditions. The situation of each country needs to be evaluated to verify whether these conditions are met and, if not, identify an action plan to make the adjustments considered essential. Other conditions not mentioned here may be needed for a given country and could be identified in such evaluations. 
There are four major conditions that a country needs to attend if the implementation of a FVL based forest policy concerned with negative S\&WRE is to be successful. Ideally, there needs to be: sufficient basis for the policy in the forest legislation; a legal support in the land property rights norms to apply the Polluter-Pay Principle; clear land tenure so that landowners responsible for land use decision making are well identified; and the elimination of distortions in land use decision making created by agriculture, forest, or other legislation or policies.

First, the forest legislation in force in a country must have a clause similar to the policy directive mentioned in box 9. This would require the definition of some form of FVL and the nature of the uses that can be applied to them. As presented in annex 3, forest legislations in several LAC countries already have some reference to FVL, although some times using different names, as part of an usually complex set of norms. Sometimes the norms have very precise and complex definitions, in others, not as much. In most cases the concept is not operationally defined which makes the implementation of the policy difficult. In some cases, these norms require that FVL must have forest use; while in other cases the purposes of the policy intervention includes addressing issues related to other externalities to which these lands are not necessarily suitable to produce (such as biodiversity preservation, aesthetics, and recreation). In yet other cases, the lawmaker confused land vocation with land capability. These variations in the definition and use of the FVL concept have made the implementation of such policies less simple and more costly to implement than needed and described here. To be adequately applied and take full advantages of FVL based forest policies, these legal variations or their interpretations would have to be adjusted.

The definition should concentrate on the necessary variables so that the operational aspects of the policy implementation are simpler and cost effective. Critical variables that may be mentioned are landscape topography and soil erodibility. Rainfall or climatic conditions may be necessary in countries where these factors are important to identify erosion prone soils. The criteria should be simple and transparent so that identification of FVL avoids discretional interpretations.

Second, it is necessary that the legislation allows the limitation of land property rights so that the PolluterPay Principle can be applied. This condition is important because it gives the legal basis to decide who pays for the necessary soil and water conservation measures to be adopted by landowners to avoid negative externalities. If landowners have the right to "pollute", i.e., have the legal or presumptive right to impose on society the consequences of externalities, society would have to pay landowners to conserve soil and water at a cost for the fiscal budget. On the other hand, if society has the right to an environment free from these externalities, it is the obligation and responsibility of landowners to undertake protective measures at their cost. The latter situation is the one assumed in this study, although the policies could work as well if the society has to pay for the soil and water conservation measures (OECD, 2001 and OECD, 2004b). It is, however, indispensable to have the rights and obligations clearly defined so that the operational aspects of policy implementation can be properly adjusted.

Third, clear land tenure is essential so that landowners responsible for land use decision making are well identified. Besides all the consequences related to unclear land tenure (Jaramillo and Kelly, 1999), to know the responsible agent for decisions regarding the use of a site is critical so that the state can take appropriate measures to assure compliance with regulation and, hence, the internalization of S\&WRE.

Lastly, it is important the elimination of distortions in land use decision making created by agriculture policies or other forest policies, and improve the harmonization of sectorial policies affecting land use. It is common that land uses, such as certain agriculture crops, are privileged by agriculture policy in a way that would lead landowners to use their land more intensively than they would otherwise. This subsidy or equivalent can make the respective land rent greater and lead landowners to encroach on FVL, thereby generating negative S\&WRE. Elimination of such distortions would make landowners respond to prices 
that better reflect the real scarcity of inputs and outputs. By doing so, land rent will induce landowners to allocate less land to crop production and more to less-intense uses, including forest uses. Some other forest policies may also work against sustainable forest production and make forest land uses yield smaller land rent (Nascimento and Tomaselli, 2005). When that is the case, forest land use will be less attractive to landowners and agriculture use--which will need greater protective measures--could occupy forest vocation lands.

If the specific situation of a given country in regard to these four conditions is essentially a matter of degree and not of kind, FVL based forest policy implementation can be initiated. However, the success of the implementation will probably be greater if these conditions are fully satisfied.

\section{Operational aspects}

The simplicity of the conceptual and of the operational aspects of its application are some of the major advantages of FVL based forest policies, especially for the contingencies found in less developed countries. Here, three basic operational aspects will be discussed: the identification of FVL, the monitoring of land cover and its change, law enforcement activities, and the dissemination of the rules of the game. These are activities necessary for the implementation of the operational aspects of the policy, but they are probably not sufficient. Country contingencies may require additional activities, but the ones discussed here are of critical importance.

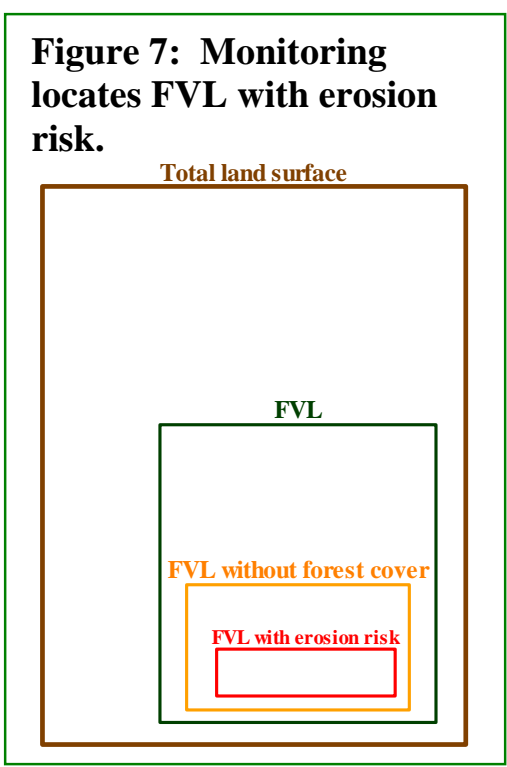

\section{Identification of FVL}

It is critical to know where the FVL are located. These are the only areas where there is need for enforcement of a FVL based forest policy. The identification of these areas is a one-time event whose results are unlikely to change over time, since they depend exclusively on natural features of the terrain. It is not necessary to identify vocation lands for agriculture or any other use.

The first step in the identification of FVL is the exclusion of areas that are not likely to generate negative S\&WRE in rural areas, such as, deserts and other drylands, urban areas, and bodies of water. Officially protected units such as national parks and other areas allocated for the in situ preservation of genetic resources can also be excluded since they are not subject to land use change ${ }^{7}$. On the remaining surface area, the identification of FVL will depend on the specific criteria established in the relevant norms. For the sake of an example, here the basic criteria used will be surface topography for areas of slope gradient superior to $30 \%$, and additionally soil erodibility for lands between $8 \%$ and $30 \%$. The information on slope gradient can be obtained from topographic maps and/or from satellite images with relative ease and low cost. Algorithms similar to those applied by Fischer, van Velthuizen, Shah and others (2002), can be adjusted to identify the lands with the features mentioned. Lands with slope gradients superior to $30 \%$ can be considered FVL without any other consideration, while lands with gradients inferior to $8 \%$ are considered non-forest vocation lands and also need no further analysis.

In areas with slope gradients between $8 \%$ and $30 \%$, soil erodibility data will be necessary to identify the areas more prone to erosion and which, therefore, must be considered FVL. Soil maps are available for

\footnotetext{
${ }^{7}$ These areas must be identified and monitored to assure their proper use but not for the sake of implementing a FVL based forest policy.
} 
most countries, albeit with different levels of precision and scale. When necessary, additional sampling of soil characteristics used to determine erodibility (contents of sand, silt and clay) can be analyzed to improve the classification. Soil specialists are capable of identifying soils with greater or less risk of erosion. Those soils that would require soil and water conservation measures are classified as FVL while more stable soils are classified as nFVL.

Of course, there is still substantial quantity of work behind this identification and misclassification of land is possible. The procedure should include public consultation to allow landowners and other stakeholders to request classification reviews. The identification process can be sequential in terms of regions, especially in larger countries. In these cases, it is recommended that priority be given to lands which are better located, and that are generating negative S\&WRE and already reducing social welfare.

The methodology summarized illustrates the level of difficult and cost involved in the identification of FVL. It should be clear by now, that other land or soil classification and planning methodologies mentioned here are much more complex, and costly.

\section{Monitoring activities}

The policy requires the periodic monitoring of only FVL to verify land cover and its changes. The main objective of the monitoring system is to identify areas with no forest cover. These areas may have an unsustainable cover, i.e., they are FVL with erosion risk, and potentially producers of negative soil or water related negative externalities (see figure 7). The principal indicator to be monitored is the cover of forest vocation lands, and it suffices to know whether forest cover is present or not.

The forest cover presence indicator can easily be determined using remote sensing methodologies. As this information is available for more than one period, it is possible to locate sites where recent changes have taken place and their types (figure 8) can be determined later. For areas found to have no forest cover, and are not known to have a sustainable land use, an additional indicator, current land use, needs to be obtained. Although the current land cover indicator only needs to have three possible values (sustainable, temporary, and unsustainable land covers), determining which one applies to a given are may require an in situ inspection by enforcement personnel.

Among the areas found without forest cover, recently deforested sites are of especial concern and should be designed as priority for further investigation. The purpose of such inspection is to find out whether they are a result of a cover chance type ACB, ACD, AB, or AD. Regardless of the cover change type, the critical information for the purpose of the policy enforcement is to detect whether the area has an acceptable land cover or not (figure 8).

The basic indicators measured and others easily obtainable at little marginal costs can be further analyzed for other purposes (Nascimento, 1991). The above indicators, however, are the few critical ones needed for the adequate enforcement of the policy, as discussed below.

Successive monitoring periods can pay also especial attention to areas where land cover changes are expected as a consequence of the plans landowners of FVL without forest cover have committed

\section{Figure 8: Land cover change types and acceptable land covers.}

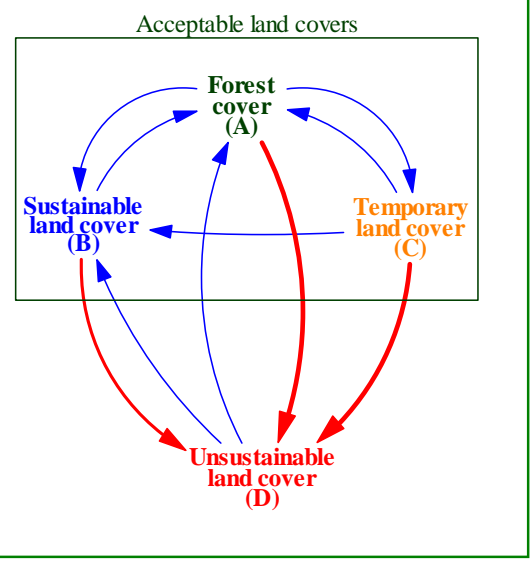
to implement (see below). Lack of evidences demonstrating landowners' efforts to improve land use is sufficient motive for further in situ inspections and eventual punitive measures. 


\section{Policy enforcement}

Enforcement of the FVL based forest policy is relatively simple, with few requirements from landowners, and goes to the heart of the externality concerns of society, i.e., it concentrates efforts on the type of cover landowners choose for their FVL.

Figure 9 summarizes the basic decision tree for the typical enforcement procedure. The policy requires only that forest vocation lands be covered with forests of any kind or, if they are not covered with forests, that landowners demonstrate that their current land cover is not generating soil or water related externalities (sustainable use), or that the current cover is a transition phase to a more sustainable land cover.

The first step of the enforcement process is to evaluate the indicators of land cover on FVL collected by the monitoring activities discussed above. The purpose of this initial evaluation is to identify the FVL without forest cover. FVL areas with forest cover needs no further enforcement action. FVL without forest cover needs complementary in situ inspections to detect evidences of misuse.

\section{Figure 9: FVL based forest policy enforcement decision tree.}

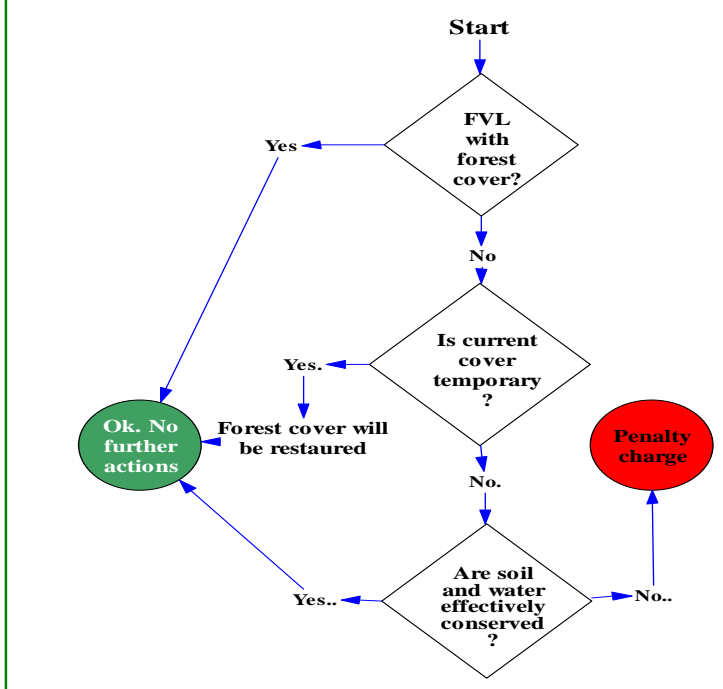

Secondly, policy enforcers may find during inspections that the landowner of a recently deforested area has plans and is undertaking actions with the goal of returning the area to forest use, in which case no further enforcement action is needed. The landowner of this FVL with a temporary land cover must be prepared to present evidences of the existence of such plans and/or show the results of actions taken in situ towards reaching that objective.

If the landowner is planning to use other type of sustainable land use, it should show evidences of such a plan and respective actions. Otherwise, the landowner will receive a penalty charge. In addition, any evidence of erosion would be enough for enforcers to demonstrate that the landowner is not adopting an acceptable and sustainable land cover.

Any non-compliance would then be penalized by a charge (see figure 9). The value of the penalty charge, in principle, must be large enough to provide incentives for landowners to adopt soil and water conservation measures. The charge should reduce the private land rent enough to make the landowners' most profitable alternative sustainable land use, their best choice. This is the only type of enforcement necessary to apply a FVL based forest policy.

Some countries may opt to give a grace period to landowners who were uninformed about their responsibilities, so that they can adjust and comply. In this case, formal warnings should be issued and their areas should be singled out for special monitoring.

This process should be repeated at least once a year so as to detect FVL with no forest or other sustainable land cover. The yearly risks of being penalized that these landowners would face if they choose not to 
have an acceptable land cover, provide additional incentives for compliance. Landowners would continue to be penalized each year until they take action to comply.

To discourage discretionary behavior and corruptive acts, enforcers and landowners would have to be supported by proper documentation so that transparent appeal procedures can be applied. Other techniques to verify the performance of enforcers should also be used.

Although this brief enforcement procedure may seem complex, it is much less so than the procedures currently in place in many LAC countries (e.g., FAO, 2005c).

\section{Dissemination of the rules of the game}

The last critical operational aspect for the successful implementation of a FVL based forest policy is the dissemination of the rules of the game among landowners and society in general (FAO, 2005d). Landowners of FVL, in particular, should have information that allows them to understand the reasons for these rules, their obligations and rights, and the enforcement and appeals procedures. Dissemination of the rules of the game is a continuous activity, and should be part of the tasks of enforcers as well. Landowners should also be supported with information on sustainable technologies that they may apply so as to comply with the policies. Soil and water conservation technologies are well known in the academic world (e.g., FAO, 1989 and 1989), and should be made available in appropriate format to FVL owners. However, as mentioned above, it would be counter to the purpose of the policy and the Pollution-Pay Principle if landowners are subsided to help them adopt proper conservation measures.

\section{Other forest policy implications}

This section has the intent of exploring some of the consequences of the adoption of a FVL based forest policy to common forest policy issues, such as biodiversity preservation, carbon sequestration and stock, illegality in forestry, payments for environmental services, and the impacts on the poor that depend on the FVL.

\section{Biodiversity preservation}

As discussed above, TVF based policies may contribute marginally to the adequate provision of externalities related to genetic resources. This is because, to be effective, biodiversity conservation requires mostly intact lands in relatively large areas sufficient to sustain a representative and ecologically fully functional sample of the ecosystem of interest. In situ preservation of genetic resources involving small and generally fragmented areas is ineffective. If an ecosystem in need of preservation covers FVL, the policies recommended here will not assure its preservation. Other instruments based on complementary policies, usually as part of the norms governing protected areas, will have to be used.

The land rent discussion above, however, is useful to stress the need for adequately addressing the issue of compensation for the opportunity costs of landowners that are located in buffer zones or inside protected areas. In cases where buffer zones and FVL overlap, opportunity costs are usually smaller than in AVL because of the need for investments in soil and water conservation measures. This tends to reduce land rent and make it cheaper to compensate landowners for these relatively smaller opportunity costs. 


\section{Carbon sequestration and stock synergy}

The provision of carbon related externalities can benefit from FVL based forest policies because these lands will tend to have a forest cover, which will sequestrate carbon as it grows and stock it in the forest biomass. However, FVL landowners will continue to ignore this social benefit in their land use decision making if they are not compensated for its production. If such payments are made, land rent associated with forest uses will increase for each land quality and forest use or cover tend to extend over marginal lands. There is, therefore, a positive synergy between policies that promote carbon sequestration and stock increase and FVL based forest policies.

\section{Illegality in forestry can be reduced}

As quoted in box 10, the legality of wood production has been a subject of debate. Illegality, of course, requires non compliance with laws. However, as exemplified in the discussion below about two common but critically intrusive forest norms, not all laws are alike. Indeed, many of the current forest legislations has been too complex, restrictive, costly to comply with and enforce, and has created too often situations that lead to corruptive behavior. Along with market failures, these policy failures create major constraints for sustainable forest businesses development (Nascimento and Tomaselli, 2005).

The FVL based forest policy framework presented in this paper, however, helps to address several issues related to illegal forest

Box 10: The importance of illegality for forestry.

Forest law enforcement is one of the most debated issues in the international forestry arena today. Illegal forest production dwarfs legal production in some countries. Illegal land clearance gives rise to severe problems with deforestation and forest fires. And illegal trade tars all forest products from some regions with a negative image. Hosny El-Lakany and Manuel Sobral Filho, Forward to FAO, (2005d).

practices. First, it simplifies requirements of the forest law. The policy needs legislation that focuses on the way FVL are used and does so with simple requirements, easily and inexpensively monitored and controlled.

Second, the overall streamlining of the forest norms diminishes the activities and actors controlled and, therefore, the instances in which illegality could take place.

Third, fiscal resources dedicated to the enforcement of extensive controls, can be reallocated to other social priorities, including the enforcement of the simpler FVL based requirements, or to the preservation of genetic resources, instead of being dispersed in the control of too many issues and actors.

Finally, the simplified framework offered by the FVL based policies, reduces forest businesses costs associated with law compliance and corruptive situations, improves forest use competitiveness, and make forest investments more attractive, thereby helping landowners to profitably use their FVL in forest uses.

The discussion of the differences between current forest typical regulatory framework and the FVL based policies and supporting legislation, will concentrate on two common requirements: management plans to obtain wood production licenses; and the related issue of custody chain control.

\section{Management plans requirements not needed}

Management plans originated from landowners' need to obtain the maximum benefits from their forests. They helped landowners to decide when and how to cut and plant trees, what silvicultural treatments to apply, etc. Years latter, some governments concerned with the destruction of natural forests and the production of related externalities, decided to establish a mechanism that assured that forest goods where being produced in appropriately managed forests. They included in the forest legislation requirements 
that landowners must have management plans approved by government officials before a license to cut trees could be issued. The purpose was to assure sustainability of the forest production. The level of details required for these plans varies substantially, but usually overzealous bureaucrats have tended to ask for too many details, increasing compliance costs. This distortion on the purpose of management plans transformed an instrument that assisted landowners to manage their forests into a costly bureaucratic conditionality frequently ignored when forest owners make their real production decision.

The diversity of forest land contingencies should make management plans quite varied. This variety usually has led government enforcers plenty of room for discretionary evaluations and opportunities for corruptive behavior (see also FAO, 2005d). Further more, a forest management plan requirement for landowners has yet to demonstrate that it can assure society the adequate provision of genetic resources preservation or the production of carbon related externalities. It seems that what it has accomplished is to increase forest production costs, reduce the corresponding land rent that landowners can obtain from it, and make forest land uses and businesses less competitive. The unintended consequences of this requirement may actually be an incentive for landowners to convert forests into other lands uses that ironically are not usually restricted by any licensing norms. In addition, monitoring of the implementation of such management plan by the state requires substantial human and material resources and additional opportunities for corruptive behavior.

In contrast, to reach its objective, FVL based forest policies do not need to require that FVL landowners have any type of license, let alone one that depended on the approval of a forest management plan. It requires only that FVL have a forest cover or another sustainable land use. These simplified requirements reduce the landowners' burdens of complying. It also reduces the controls that government would otherwise have to conduct.

Forest management plan is a management tool that should be part of a business plan. By itself, it brings no added value to the landowner (or society) unless it is useful to improve production and productivity. Its use should be a business necessity but there is no purpose for a government intervention to demand the use of this tool if a FVL based forest policy is applied.

\section{Custody chain controls become unnecessary}

One inevitable consequence of the license requirement to cut trees is usually the need to make sure that authorized logs and wood products do not get mixed up with products from areas without approved forest management plans. Governments, however, had no practical ways to control all forests. A solution came in the form a proxy control strategy. To control the wood origin and make sure that the product came from forests with management plans and properly licensed, governments had to introduce controls to allow the monitoring of wood on the roads, on the factory floors, and in some cases till consumption; they had to control the steps of custody chain. This additional control on forest production unprecedented if compared to other competitive lands uses, has further reduced forest competitiveness and increased the opportunities for discretional and corruptive behaviors. This type of control has made wood transporters, wood industrialist and other entrepreneurs to become aware of the origin of the wood they work with since they are usually made responsible for any unauthorized wood found in their custody. They have become indirect enforcers of the management plan licensing scheme, creating substantial conflicts with their normal businesses interests. The development of technologies that now allow a better monitoring of forest areas has apparently not decreased the use for these controls or resulted in the questioning of the need for such proxy strategy.

FVL based forest policies are concerned with the production of externalities associated with their sustainable use. Hence, all monitoring and enforcing effort is directed to the forest vocation land itself, in 
situ. It is unnecessary to control the chain of custody, with the obvious benefits in terms of reduced wood production, transaction, and monitoring and enforcement costs.

\section{Payments for environmental services are important complements}

FVL based forest policies do not require the payment for the associated soil and water environmental services, because landowners are not generating a net social benefit by using FVL sustainably, but merely avoiding the costs they would otherwise impose on society. No payments are due to those that are simply avoiding the costs they can generate to society. This conclusion is the result of the land property rights assumption made here, and often valid in LAC countries, that landowners have no absolute right to impose externalities on society.

Other environmental services discussed here would, however, merit such payments. The welfare improvement generated by the sequestration or stock of carbon by wood biomass certainly could be compensated so that FVL landowners would increase the production of such benefits. As mentioned above, this would bring a favorable synergy with the soil and water conservation as forest land uses become more attractive.

Biodiversity preservation services related payments in buffer zones that make ecosystem's sample preservation more feasible also would contribute to improve FVL land use where they overlap. However, the reversed situation is not as useful.

\section{How about the poor in the FVL?}

FVL based forest policy as presented here depends on the assumption that landowners have no right to generate negative S\&WRE and that society has the right to be free from such externalities. Landowners, therefore, are responsible for any investments needed to comply with such a policy. They would have not only to pay for soil and water conservation measures and forgo the private benefits of more land use alternatives, but would also have to pay for the restoration of already degraded FLV so that the production of externalities may cease.

One could ask how this policy would affect poor landowners of FVL. The issue is really one of poverty rather than proper land use. These unfortunate persons already face substantial hardships and the poor quality of their lands gives little hope for them to prosper under such adverse circumstances. If these poor landowners are asked to pay charges for their misuse of FVL and generation of negatives externalities for the rest of society or invest to avoid them, it may become even clearer that their private land rent will become much smaller if not already negative. Not to charge these landowners for the damage they generate to society represents a de facto subsidy from society so that they can keep generating externalities to the detriment of society's welfare. This is the case of a poverty problem located in the forest, and not primarily a forest problem of the poor. However, addressing such a problem is such a difficult task that some may tacitly prefer to pay the environmental cost to keep the problem far away on the forest land.

Nevertheless, for some of these poor, given the right conditions, forests can help combat poverty and improve their quality of life. Several alternatives could be envisioned to address this situation. Here, two are explored. First, poor landowners of FVL could be helped to become more competitive by adopting more productive forest technologies. They could be supported to integrate horizontally with their neighbors to increase land scale and adopt more competitive forest technologies and business practices, and create new businesses and job opportunities. They could also be helped to integrate vertically with the forest industry and become partners with it; thereby obtaining income and freeing time for the sale of labor (see Nascimento and Mota Villanueva, 2004). 
The other alternative, which is not mutually exclusive with regard to the first one, could be to apply instruments and policies that address poverty directly to benefit these poor FVL landowners. They could receive support to improve their heath, nutrition, and education. With improved skills and health, these poor would be better able to use their resources-labor, FVL, entrepreneurship - to advance their quality of life. Even with these supports, some of the poor in the FVL may never be able to apply a sustainable land use to generate income and prosper without producing negative S\&WRE for society, unless society pays them not to use these lands. However, the resulting improved conditions from poverty combating strategies combined with additional support from the state-reducing taxes and other land exchange transaction costs, providing information that facilitate land market transactions-may lead some to find it to their advantage to redeploy the resources they control elsewhere in the economy, thereby allowing FVL to be used in sustainable land uses by others while improving their own quality of life.

It is very likely, though, that ignoring the situation of these poor families by allowing, indeed subsidizing, them to continue misusing FVL will neither solve their poverty problem, nor address the externalities problem. In fact, the continuous land degradation expected to result from such misuse, will probably aggravate their poverty. The poor in FVL faces a vicious circle where their misuse of these lands degrade the resources, reduce thereby their income generating capability, and make them even poorer over time. 


\section{Conclusions}

The basic results of the study are summarized in box 11 .

The negative externalities resulting from unsustainable use of forest vocation lands are the main market failure that concerns the group of forest policies and government actions designed to assure their adequate provision and, thereby, improve social welfare. Forest based externalities can be group in 4 classes as they relate to soil and water; biodiversity, carbon sequestration and stock, and aesthetic services. Each of them has specific characteristics that determine how they are produced and the technical constraints for policies of the second group (i.e., those concerned with the proper provision of forest related externalities) that try to assure their adequate social provision.

Aesthetic externalities are usually based on a unique feature of the forest landscape, and, for the most part, their benefits require physical presence on the site. These facts indicate that, if exclusion of non payers is possible, locals and visitors could be charged to enjoy such benefits. There is no need for a policy that affects many landowners when the only affected ones should be those directly involved in the locality where they occurs.

\section{Box 11: Basic results of the study:}

Forest policy concerns itself with welfare. There are two basic groups of forest policies: 1) those related to the provision of private goods and services; and 2) those related with the adequate provision of forest based externalities. The latter is the main concern of this paper.

Forest based externalities can be divided in four basic types involving issues related to: soil and water; biodiversity, existence and option values; carbon sequestration and stock; and aesthetic.

Genetic resources preservation depends on the preservation of effective samples of unique and fully functioning ecosystems where they are found. Their preservation depends neither on the physical natural of the site, nor on any forest cover but rather on a very particular type of forest cover, an untouched forest ecosystem. Hence, any forest use may result in the partial destruction over time of the resources.

Carbon sequestration and stock externalities can be produced by growing forests almost anywhere they can be grown and benefit humanity in general. This imply that forest policies concerned with carbon related externalities also are not site relevant and should seek that global beneficiaries pay for them.

Aesthetic externalities are usually based on a unique feature of the forest landscape, and, for the most part, their benefits require physical presence on the site. These facts indicate that, if exclusion of non payers is possible, locals and visitors could be charged to enjoy such benefits. There is no need for a policy that affects many landowners when the only affected ones should be those directly involved in the local where it occurs.

Soil and water related externalities (S\&WRE) are present anywhere the soil slope and length are high, soil has risk of erosion, rainfall has sufficient erosive power, land cover is not protective, and land use does not adopt conservation measures. These features require a forest policy solution that can be applied to all areas under risk.

Soil and land use planning methodologies are useful for the understanding of the factors and conditions determining S\&WRE, as well as help in the formulation of a framework for the design of public policies to address them. However, they are costly; and require lots of data, manpower, equipments and materials to be properly applied, making them, in some cases, almost unfeasible to be applied by the average developing country.

Forest vocation lands (FVL) are those that, due to their physical site features such as soil, topography, and the rainfall it receives, should be kept under forest cover or other sustainable land use if soil or water related negative externalities are to be avoided. FVL classification does not depend on the type of cover the land actually has, nor does it depend on the requirements it may have for agriculture crop or forest production. Therefore, lands with no forest cover or use can still be classified as FVL if their physical features so indicate; while lands covered with forest may not be FVL.

Good or bad deforestation depends on land vocation, on the land use given to the site afterwards, and on its respective rent. Good deforestation refers to the maximization of rent of the new land use at the same time that negative S\&WRE are not present. Bad means that either land rent is not being maximized or that soil and water externalities are affecting adversely society, or both.

The principal directive of a forest policy of the second group that is based on the concept of FVL is that they should be covered by forests or used with a sustainable land use if no negative S\&WRE are to reduce social welfare. 
FVL based forest policies are especially useful for developing counties because they are relatively easy to understand; are less intrusive in the forest business decision making processes and, thereby, allow for greater freedom of action; are less costly to monitor, enforce, and comply with; reduce corruptive activities and illegality associated with forests; and do not require adjustments as technologies and market conditions change.

There are four major conditions that a country needs to attend if the implementation of a FVL based forest policy concerned with negative S\&WRE is to be successful: sufficient basis for the policy in the forest legislation; a legal support in the land property rights norms to apply the Polluter-Pay Principle; clear land tenure so that landowners responsible for land use decision making are well identified; and the elimination of distortions in land use decision making created by agriculture, forest, or other legislation or policies.

The implementation of a FVL based policy requires the following basic steps: the identification of FVL, the monitoring of land cover and its change, law enforcement activities, and the dissemination of the rules of the game.

TVF based policies may contribute marginally to the adequate provision of externalities related to genetic resources.

There is a positive synergy between policies that promote carbon sequestration and stock increase and FVL based forest policies.

Illegality in forest activities is likely to reduce when a FVL based forest policy is implemented. In addition, licensing and management plan legal requirements or custody chain controls by the state are not needed to accomplish society's goals when a FVL based forest policy is adopted.

FVL based forest policies do not require the payment for the associated soil and water environmental services.

The poor in FVL faces a vicious circle where their misuse of these lands degrade the resources, reduce thereby their income generating capability, and make them even poorer over time. They need to be assisted in adopting more sustainable land uses and they must benefit from the same policies that combat poverty in other areas of a country. Combined with additional support from the state-reducing taxes and other land exchange transaction costs, providing information that facilitate land market transactions - the latter assistances may lead some of the poor for which there is no hope for them to use sustainable land uses, to find it to their advantage to redeploy the resources they control elsewhere in the economy, thereby allowing FVL to be used in sustainable land uses by others while improving their own quality of life.

Carbon sequestration and stock externalities, in contrast, can be produced by growing forests almost anywhere they can be grown; they are ubiquitous in terms of where they can be produced. These externalities benefit humanity in general and not a specific group. This imply that forest policies concerned with carbon related externalities also are not site relevant and should seek that global beneficiaries pay for them. The Kyoto mechanism seeks to address these features.

Genetic resources preservation depends on the preservation of effective samples of unique and fully functioning ecosystems where they are found. Their preservation depends neither on the physical natural of the site, nor on any forest cover but rather on a very particular type of forest cover, an untouched forest ecosystem. Hence, any forest use may result in the partial destruction over time of the resources. Fragmented areas covered in part or totally by natural forests cannot serve as a basis for a prudent policy for the preservation of genetic resources because they keep degrading over time inevitably reducing their value. To be covered by natural forest is neither sufficient nor necessary to assure the preservation of the genetic resources found therein. Restrictions on land use in natural forest areas located in buffer zones around protected areas, however, may be a useful complementary strategy to help in the long term maintenance of the protected areas.

S\&WRE have a combination of features that require a particular approach to assure their adequate provision to society. Not being unique to a few sites, these externalities are present anywhere the soil slope and length are high, soil has risk of erosion, rainfall has sufficient erosive power, land cover is not protective, and land use does not adopt conservation measures. These features require a forest policy solution that can be applied to all areas under risk. In addition, the beneficiaries of such externalities are in part the landowners, and also the local society.

Due to the features mentioned, this paper concentrated the discussion on issues related to S\&WRE.

Soil and land have been described and classified with various purposes; including the identification of those areas at most risk for S\&WRE. The paper clarified concepts, helped to form an understanding of the main features of land that affect production, productivity and externality, and contrasted the several 
ways by which land can be classified. Land use planning methods also have been discussed, especially as compared with vocation land classification. Land use planning methods have been found to be complex and resource demanding, often much beyond the capabilities of LDC.

Forest Vocation Lands are those that, due to their physical site features such as soil, topography, and the rainfall they receive, should be kept under forest cover or other sustainable land use if soil or water related negative externalities are to be avoided. FVL classification does not depend on the type of cover the land actually has, nor does it depend on the requirements it may have for agriculture crop or forest production. Therefore, lands with no forest cover or use can still be classified as FVL if their physical features so indicate while lands covered by forests may not be FVL.

Despite the extensive application by LAC legislators of the FVL concept, the discussions about it in the forest policy literature are surprisingly few. The extensive use of the concept in forest legislation may be related to its intuitive nature, the easiness of identification by landowners and law enforcers, and its cost effectiveness. This paper also tries to contribute to fill this gap in the policy discussion.

The basic requirement for the proper use of FVL is that they should be covered by forests or be used in such a way as not to generate soil erosion and water conservation related negative externalities for society. When this requirement becomes law, landowners have their land use options for FVL limited to those which will not generate these types of externalities. By only being allowed to use these lands in nFVL uses if they effectively conserve soil and water by investing in protective measures, landowners are actually internalizing these externalities in their decision making and complying with the Polluter Pay Principle. This can be so only if landowners have no right to impose on society such externalities.

The paper discusses the land rent model and its usefulness to explain the land use decision making, the concept of opportunity cost, and their relationships to FVL concept. The model helped to identify the possible land use, cover, and vocation scenarios and the conditions where deforestation is good or bad for society as a whole. The analysis found that there are two basic scenarios that are of concern for forest policy: the case where FVL are being used for unsustainable agriculture, or the case where they have no forest cover or use. The unsustainable agriculture use can be profitable to landowners only because they do not adopt soil and water conservation measures. This misuse would generate no land rent, be unprofitable but produce no social cost if negative externalities were internalized. However, this is not usually the case and the continuous unsustainable agriculture use of FVL is the most damaging scenario for society and the principal concern for forest policy.

Good or bad deforestation depends on land vocation, on the land use given to the site afterwards, and on its respective rent. Good deforestation refers to the maximization of rent of the new land use at the same time that negative S\&WRE are not present. Bad means that either land rent is not being maximized or that soil and water externalities are affecting adversely society, or both.

This study found that there are 4 cases in which deforestation can be good for society and for landowners. Deforestation is good in the instances where the new land use generates the greatest land rent and is sustainable, i.e., does not generate negative externalities. This happens when a natural forest covering a forest vocation land is deforested but the land is latter used for forest use when it is the one that generates the greatest land rent, or the land is used for sustainable agriculture when this land use generates the greatest land rent. Not to deforest in these four scenarios means that society and landowners are paying an important opportunity cost, since the social and privately more profitable sustainable land use will not collect the land rent that they can produce. 
Conversely, bad deforestation was found in 12 of the 16 possible scenarios studied. Bad deforestation was found whenever forest covered land is being converted to a lesser profitable or unsustainable land use.

The paper consolidates a proposal for a forest policy based on the forest vocation land concept, and discusses some of its implications. It presents: the policy framework with a description of its basic features; the arguments justifying the claim that this policy is simpler and less expensive to apply and comply with than comparable policies; the conditions necessary for the successful implementation of the policy; and some key operational aspects of its adoption.

The principal directive of a forest policy of the second group that is based on the concept of FVL is that forest vocation lands should be covered by forests or used with a sustainable land use if no negative S\&WRE are to reduce social welfare.

Lastly, the paper explored some of the consequences of the adoption of a FVL based forest policy to common forest policy issues, such as biodiversity preservation; carbon sequestration and stock, illegality in forestry as related to management plans and controls of custody chain; payments for environmental services, and poverty in the forest. It was discussed, for instance, why licensing and management plan legal requirements or custody chain controls by the state are not needed to accomplish society's goals when a FVL based forest policy is adopted.

Forest vocation land is a useful concept for the design of forest policies concerned with the adequate provision of forest related externalities. These policies are especially useful for LDC because they rely less on command and control restrictions; preserve and landowners and forest entrepreneurs' greater freedom in productive decision making thereby reducing opportunity costs of compliance; are simpler and cheaper to monitor, enforce, and comply with; and are less discretionary, and generate less corruptive situations and illegalities.

It is hoped that a better understanding of the theoretical aspects of the concept, its implications, and limitations will help countries to reevaluate its use in their forest policy framework. Doing so may improve the effectiveness of government interventions that seek to assure to society the adequate provision of forest related externalities. 


\section{Bibliography}

Amber, B. and others, 1999. Land Use Planning Methods, Strategies and Tools. Eschborn, Germany: Deutsche Gesellschaft für Technische Zusammenarbeit (GTZ) GmbH.

Barlowe, R., 1978. (3rd. ed.) Land Resources Economics: The Economics of Real Estate. Englewood Cliffs, New Jersey: Prentice-Hall, Inc.

Baumol, William, and Alan S. J. Blinder, 2005. Economics: principles and policies. 10th ed. Mason, Ohio: Thomson/South-Western.

Bawa, Kamaljit S. and Reinmar Seidler, 1998. Natural Forest Management and Conservation of Biodiversity in Tropical Forests. Conservation Biology. Vol. 12, No.1, 46-55.

Bosworth, Dale, 2003. Sustainable forest management: Moving forward together. Invited paper to the XII World Forest Congress. Quebec, Canada. Available in the Internet at http://www.fao.org/DOCREP/ARTICLE/WFC/XII/C16-E.HTM

Di Gregorio, A., and L.J.M. Jansen, 2000. Land Cover Classification System (LCCS): Classification concepts and user manual. Environment and Natural Resources Service (SDRN), GCP/RAF/287/ITA Africover - East Africa Project and Land and Plant Nutrition Management Service (AGLN). In the Internet at http://www.fao.org/DOCREP/003/X0596E/X0596E00.HTM

Editor, 2004. Opinion: Local Resources and Global Assets - Saving the Rainforest. The Economist, July $22^{\text {nd }}, 2004$.

EMBRAPA Solos, SD. Sistema Brasileiro de Classificação de Solos. Available in the Internet at http://www.cnps.embrapa.br/search/novids/oqvai8/oqvai8.html

EMBRAPA Solos, 1999. Zoneamento Pedoclimatico para Pinus elliotti no Estado de Santa Catarina. Rio de Janeiro: EMBRAPA SOLOS. (Documentos no. 9).

FAO, 1989. Manual de campo para el manejo de cuencas hidrográficas. medidas y prácticas para el tratamiento de pendientes. Guías FAO: Conservación 13. Roma, Italia: Food and Agriculture Organization of the United Nations (FAO). Available in the Internet at http://www.fao.org/documents/show cdr.asp?url_file=/DOCREP/006/T0140S/T0140S00.HTM

FAO, 1993. Guidelines for land-use planning. FAO Development Series No. 1. Rome, Italy: FAO. Available in the Internet at http://www.fao.org/docrep/T0715E/T0715E00.htm

FAO, 1996. Agro-Ecological Zoning: Guidelines. FAO Soils Bulletin 73. Soil Resources, Management and Conservation Service. Rome, Italy: FAO. Available in the Internet at http://www.fao.org/docrep/W2962E/w2962e00.htm

FAO, 1998. Watershed management field manual. Road design and construction in sensitive watersheds. FAO Conservation Guides, 13/5. Rome. Italy: FAO. Available in the Internet at http://www.fao.org/documents/show_cdr.asp?url_file=/DOCREP/006/T0099E/T0099E00.HTM 
FAO, 2000. World Soil Resources Report 90: land resource potential and constraints at regional and country levels. Rome, Italy: FAO. Available in the Internet at ftp://ftp.fao.org/agl/agll/docs/wsr.pdf .

FAO, 2001. State of the World's Forests - 2001. (Part II - Forest biological diversity conservation: protected area management). Rome, Italy: FAO.

FAO, 2003. State of the World's Forests - 2003. Rome, Italy: FAO.

FAO, 2004. Global forest resources assessment update 2005: terms and definitions (final version). Rome, Italy: FAO. Available in the Internet at www.fao.org/forestry/site/fra2005-terms/en

FAO, 2005a. State of the World's Forests - 2005. Rome, Italy: FAO.

FAO, 2005b. Global forest resources assessment 2005: 15 key findings. Rome, Italy: FAO.

FAO, 2005c. Computerized Data Gathering and Networking as a Control and Monitoring System for the improvement of and reporting on forest management in the Amazon: the case of Brazil. By Antonio Carlos do Prado, Francisco José de Barros Cavalcanti and Paulo José Prudente de Fontes. Forest Management Working Papers, Working Paper 27. Forest Resources Development Service, Forest Resources Division. Rome, Italy: FAO (unpublished).

FAO, 2005d. Best practices for improving law compliance in the forestry sector. FAO Forestry Paper 145. Rome, Italy: FAO.

FAO, S/d-a. AEZ - Agro-ecological Zoning System. Available in the Internet at http://www.fao.org/WAICENT/FAOINFO/AGRICULT/agl/agll/aez.stm

FAO, S/d-b. A new framework for: Conservation-effective land management and desertification control in Latin America and the Caribbean. Available in the Internet at http://www.fao.org/docrep/W9298E/w9298e00.htm\#Contents

FAO, ISRIC, and ISSS, 1998. World reference base for soil resources. World Soil Resources Report 84. Rome, Italy: FAO. Available in the Internet at http://www.fao.org/docrep/W8594E/w8594e00.htm\#Contents

Fischer, Gunther, Harrij van Velthuizen, Mahendra Shah, and Freddy Nachtergaele, 2002. Global Agroecological Assessment for Agriculture in the 21st Century: Methodology and Results. RR-02-02. Rome, Italy and Luxemburg, Austria: FAO and International Institute for Applied Systems Analysis, January. CD room contents available in the Internet at http://www.iiasa.ac.at/Research/LUC/SAEZ/index.html

Gregersen, H., B. Belcher, and J. Spears, 1994. Creating Policies to Contain Unproductive Deforestation. The Environmental and Natural Resources Policy and Training Project. No.8, September. Available in the Internet at http://www.cnr.umn.edu/FR/publications/epat/policybrief8.pdf

Helms, Douglas, 1992. The Development of the Land Capability Classification, In Readings in the History of the Soil Conservation Service, Washington, DC: Soil Conservation Service, pp. 60-73. Available in the Internet at http://www.nrcs.usda.gov/about/history/articles/landclassification.html 
Jaramillo, Carlos F., and Thomas Kelly, 1999. Deforestation and property rights. Chap. in K. Keipi, (ed.), Forest resources policies in Latin America. Pp. 111-133. Washington, D.C.: Inter-American Development Bank.

Kaimowitz, David, 2003. From Rio to Johannesburg and beyond: Forest conservation and rural livelihoods in the global South. Invited paper to the XII World Forest Congress. Quebec, Canada. Available in the Internet at http://www.fao.org/DOCREP/ARTICLE/WFC/XII/C15-E.HTM

Keipi, K., (ed.) 1999. Forest Resource Policy in Latin America. Washington, D.C.: Inter-American Development Bank.

Kimmins, J. P. (Hamish), 2003. Forest Ecosystem Management: An environmental necessity, but is it a practical reality or simply an ecotopian ideal? Invited paper to the XII World Forest Congress. Quebec, Canada. Available in the Internet at http://www.fao.org/DOCREP/ARTICLE/WFC/XII/MS18-E.HTM

Laarman, Jan G., 1999. Government Policies Affecting Forests. In Keipi (ed.) Forest resources policies in Latin America. pp. 11-38. Washington, D.C.: Inter-American Development Bank.

Laurance, William F., 1999. Introduction and synthesis. Biological Conservation, 91, 101-107.

Ledec, George, and Robert Goodland, 1988. Wildlands: their protection and management in economic development. Washington, D.C.: World Bank.

Lindblom, Charles Edward, 1977. Politics and markets. New York: Basic Books.

McCormack, R. J., 1967. Land capability classification for forestry. Ottawa, Canada: Queen's Printer. Available in the Internet at http://geogratis.cgdi.gc.ca/CLI/mapping/Clipdf/English/ForestryMethodology.pdf

McNeely, Jeffrey A. et al., 1990. Conserving the World's Biological Diversity. IUCN, Gland, Switzerland; WRI, CI, WWF-US, and the World Bank, Washington, D.C.

Nascimento, José Rente, 1991. Discutindo Números do Desmatamento. INTERCIENCIA, vol. 16, no.5, (Sep-Oct), pp.232-239.

Nascimento, José Rente, and José Luis Mota Villanueva, 2004. Instrumentos para el desarrollo de dueños de pequeñas tierras forestales. Serie de Estudios Económicos y Sectoriales, RE2-04-007. Washington, D.C.: Inter-American Development Bank, October. Available in the Internet at http://www.iadb.org/regions/re2/forestal_portal/publicaciones.cfm?language=Sp\&parid=6

Nascimento, José Rente and Ivan Tomaselli, 2005. Como medir y mejorar el clima para inversiones en negocios forestales sostenibles. Serie de Estudios Económicos y Sectoriales, RE2-05-004. Washington, D.C.: Inter-American Development Bank, July. Available in the Internet at http://www.iadb.org/homeid/informe_resumen.pdf

NRCS, 2000. 1997. National Resources Inventory (revised December 2000) - Summary report. Washington, D.C. ?: Natural Resources Conservation Service (NRCS) of the United States Department of Agriculture. Available in the Internet at http://www.nrcs.usda.gov/technical/NRI/1997/summary report/report.pdf 
OECD, 2001. Improving the environmental performance of agriculture: policy options and the market. Paris: Organization for Economic Co-operation and Development (OECD).

OECD, 2004a. Handbook of market creation for biodiversity: issues in implementation. Paris, France: OECD.

OECD, 2004b. Agriculture and the Environment: Lessons Learned from a Decade of OECD Work. Paris: OECD.

Rossiter, David G., (compiler), ND. A Compendium of On-Line Soil Survey Information. Soil Classification for Soil Survey. Available in the Internet at http://www.itc.nl/ rossiter/research/rsrch_ss_class.html

Rossiter, David G., 2001. Lecture Notes Principles of Soil Classification. Soil Science Division. ITC Enschede. the Netherlands. Available in the Internet at http://www.itc.nl/ rossiter/teach/soils/psc.pdf

Sayer, J.A., J.K. Vanclay, and N. Byron, 1997. Technologies for Sustainable Forest Management: Challenges for the 21st Century. Commonwealth Forestry Congress, Victoria Falls, Zimbabwe, Center for International Forestry Research (CIFOR). CIFOR Occasional Paper No. 12.

Sen, Amartya, 1999. Development as Freedom. New York: Anchor Books.

Sfeir-Younis, Alfredo and Andrew K. Dragun, 1993. Land and soil management. Boulder: Westview Press.

STCP, 2005. Índice de Atracción A la Inversión Forestal (IAIF) - Informe final (Rev.01) para el Banco Interamericano de Desarrollo. Washington D.C.: Inter-American Development Bank. Available in the Internet at http://www.iadb.org/homeid/iaif_completo.pdf

Steenblik, Ronald, Leo Maier, and Wilfrid Legg, 1997. Sustainable Agriculture. Sustainable Development: OECD Policy Approaches for the 21st Century, OECD. Paris, Organization for Economic Co-operation and Development. 1998 Reprint.

Stenger, A. and D. Normandin, 2003. Management of the Forest Biodiversity: Feasibility, Efficiency and Limits of a Contractual Regulation. In CAB International, Forest Policy for Private Forestry: Global and Regional Challenges (eds. L. Teeter, B. Cashore and D. Zang), pp. 189-202.

UNESCO, 1974. Legend of the Soil Map of the World. Paris, France: United Nations Educational, Scientific and Cultural Organization (UNESCO).

Van Kooten, G. C. and Henk Folmer, 2004. Land and forest economics. Cheltenham, UK Northhampton, MA: Edward Elgar.

World Bank, 2003. World development report: Sustainable development in a dynamic world. New York: Oxford University Press.

World Bank, 2004. World Development Report 2005: A Better Investment Climate for Everyone. New York: Oxford University Press 


\section{Annex 1: Basic concepts and classifications related to land}

\begin{tabular}{|c|c|c|c|c|}
\hline \multirow{2}{*}{\multicolumn{3}{|c|}{$\begin{array}{l}\text { Concepts } \\
\text { Land Cover }\end{array}$}} & Description & Comments \\
\hline & & & $\begin{array}{l}\text { Refers to observed (bio) physical cover on the } \\
\text { earth's surface. }\end{array}$ & $\begin{array}{l}\text { Forest land cover refers to the earth's surface areas where forests of any type or stage of development can } \\
\text { be found. Usually to be considered forest cover, it is required that a certain percentage of the surface be } \\
\text { covered by trees, regardless of their ages or species. }\end{array}$ \\
\hline \multicolumn{3}{|c|}{ Land Use } & $\begin{array}{l}\text { Refers to the active use that people give to a certain } \\
\text { land surface. }\end{array}$ & $\begin{array}{l}\text { When a piece of land is purposely used for forest production or protection, it is said to be under forest } \\
\text { land use. A piece of land may have forest cover but not be used for forest production like in many areas } \\
\text { of the Amazon region. Of course, an area under forest land use must have a forest land cover. }\end{array}$ \\
\hline \multirow{6}{*}{ 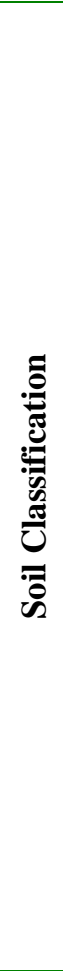 } & Natur & & $\begin{array}{l}\text { Based on some NATURAL feature of the soil such } \\
\text { as its genesis or ecological region without referring } \\
\text { to the use given to it or its potential. }\end{array}$ & $\begin{array}{l}\text { The soil criteria for these classifications are very constant over time and the information generated can be } \\
\text { used for general planning exercises as well as local level land use planning, including for forest use. }\end{array}$ \\
\hline & \multirow{5}{*}{ ֻே } & Definition & $\begin{array}{l}\text { Based on some TECHNICAL property or function } \\
\text { related to a use or group of uses such as } \\
\text { hydrological response; suitability; capability; } \\
\text { fertility; etc. }\end{array}$ & $\begin{array}{l}\text { It uses natural soil classes and various other types of information to estimate how certain land uses may } \\
\text { respond or to recommend the optimal use or non-use of the land. }\end{array}$ \\
\hline & & $\begin{array}{l}\text { Agriculture } \\
\text { land } \\
\text { capability }\end{array}$ & $\begin{array}{l}\text { Based on the intrinsic physical and chemical } \\
\text { features of the area as well as crop requirements, it } \\
\text { determines capability for agriculture production on a } \\
\text { sustainable basis. }\end{array}$ & $\begin{array}{l}\text { It tells which piece of land is more adequate for various types of agriculture products under basic } \\
\text { production systems. It reserves the best land for agriculture production, then the medium capable lands } \\
\text { for cattle raising, and to forest use those lands that cannot be usually used for agriculture or cattle raising } \\
\text { without major investment in soil erosion and water runoff conservation measures. No other externalities, } \\
\text { or market or economic factors are considered in this classification. Given certain economic conditions, } \\
\text { agriculture capable lands may be covered by forests or used in forest production. Likewise, forest } \\
\text { capable lands with additional conservation investments can be used for agriculture production though } \\
\text { rarely on a competitive basis with agriculture capable lands. This classification is quite stable because of } \\
\text { the less changeable nature of the variables considered. }\end{array}$ \\
\hline & & $\begin{array}{l}\text { Forest land } \\
\text { capability }\end{array}$ & $\begin{array}{l}\text { Based on plant requirements and site physical } \\
\text { features, defines land capability for sustainable } \\
\text { forest. }\end{array}$ & $\begin{array}{l}\text { It tells the levels of natural capacity of the land to produce trees. Forest production is very flexible. Trees } \\
\text { can be grown very well in land also classified as good for agriculture production, as well as cattle } \\
\text { production. Only extreme situations are unfavorable for some level of forest production. No economic or } \\
\text { market considerations are usually included in this classification. Therefore, it is quite stable over time } \\
\text { because of the less changeable nature of the variables considered. }\end{array}$ \\
\hline & & $\begin{array}{l}\text { Agro- } \\
\text { ecological } \\
\text { zoning }\end{array}$ & $\begin{array}{l}\text { Based on combinations of soil, landform, and } \\
\text { climatic characteristics of the site as well as climatic } \\
\text { and edaphic crops requirements and on the } \\
\text { management systems under which the crops are } \\
\text { grown. }\end{array}$ & $\begin{array}{l}\text { This classification makes the relationship between agriculture production and the environmental impacts } \\
\text { that each land use may have more explicit. It requires lots of information, technical skills, complex } \\
\text { methodologies, computer software and equipments. The results are expected to change only with changes } \\
\text { in production technology. Here, forest uses are reserved for those sites that are not proper for sustainable } \\
\text { agricultural use. }\end{array}$ \\
\hline & & $\begin{array}{l}\text { Ecological- } \\
\text { economic } \\
\text { zoning }\end{array}$ & $\begin{array}{l}\text { Integrates agro-ecological with socio-economic } \\
\text { factors and a wider range of land uses in the } \\
\text { identification of the zones. }\end{array}$ & $\begin{array}{l}\text { As it tries to match agro-ecological zoning with production costs and market conditions, this methodology } \\
\text { needs to be updated frequently to try to follow the changes on socioeconomic conditions or their } \\
\text { expectations over time. Hence, it has the basic requirements of the AEZ aggravated by the need for } \\
\text { frequent updates. Theoretically, it could identify the most profitable land use for landowners and society. }\end{array}$ \\
\hline
\end{tabular}

Source: Prepared by the author based on Di Gregorio and Jansen (2000); Rossiter (2001); Helms (1992); FAO (1996). 


\section{Annex 2: Steeplands in selected Latin American and Caribbean countries $\left(1,000 \mathrm{~km}^{2}\right)$}

\begin{tabular}{|c|c|c|c|c|c|c|c|}
\hline \multirow{3}{*}{ Country } & \multirow{3}{*}{$\begin{array}{c}\text { Total area } \\
\text { Area }\end{array}$} & \multirow{2}{*}{\multicolumn{2}{|c|}{$\begin{array}{c}\text { Steep slopes } \\
\mathbf{8}-\mathbf{3 0} \%\end{array}$}} & \multirow{2}{*}{\multicolumn{2}{|c|}{$\begin{array}{c}\text { Very steep slopes } \\
>30 \%\end{array}$}} & \multirow{2}{*}{\multicolumn{2}{|c|}{ Total steepland }} \\
\hline & & & & & & & \\
\hline & & Area & $\%$ & Area & $\%$ & Area & $\%$ \\
\hline El Salvador & 21 & 11 & 53 & 6 & 28 & 17 & 81 \\
\hline Haiti & 27 & 15 & 56 & 6 & 24 & 22 & 80 \\
\hline Honduras & 112 & 59 & 53 & 28 & 25 & 88 & 78 \\
\hline Dominican Republic & 47 & 25 & 53 & 9 & 19 & 34 & 71 \\
\hline Guatemala & 108 & 52 & 48 & 23 & 22 & 76 & 70 \\
\hline Mexico & 1,966 & 1,001 & 51 & 373 & 19 & 1,373 & 70 \\
\hline Peru & 1,281 & 5 & 52 & 2 & 18 & 6 & 70 \\
\hline Jamaica & 11 & 5 & 48 & 2 & 20 & 8 & 68 \\
\hline Panama & 78 & 40 & 51 & 11 & 14 & 51 & 66 \\
\hline Trinidad and Tobago & 5 & 2 & 44 & 1 & 22 & 3 & 66 \\
\hline Costa Rica & 51 & 24 & 48 & 9 & 17 & 33 & 65 \\
\hline Chile & 749 & 212 & 28 & 243 & 32 & 455 & 61 \\
\hline Venezuela & 910 & 382 & 42 & 146 & 16 & 528 & 58 \\
\hline Nicaragua & 144 & 59 & 41 & 19 & 13 & 78 & 54 \\
\hline Ecuador & 283 & 89 & 31 & 60 & 21 & 149 & 53 \\
\hline Guyana & 215 & 90 & 42 & 22 & 10 & 113 & 52 \\
\hline Belize & 23 & 9 & 39 & 2 & 9 & 11 & 47 \\
\hline Colombia & 1,136 & 412 & 36 & 119 & 10 & 531 & 47 \\
\hline Bolivia & 1,096 & 253 & 23 & 175 & 16 & 428 & 39 \\
\hline Brazil & 8,479 & 2,938 & 35 & 293 & 3 & 3,230 & 38 \\
\hline Argentina & 2,772 & 481 & 17 & 283 & 10 & 763 & 28 \\
\hline Suriname & 164 & 41 & 25 & 0 & 0 & 41 & 25 \\
\hline Paraguay & 407 & 63 & 16 & 0 & 0 & 63 & 16 \\
\hline Uruguay & 186 & 20 & 11 & 7 & 4 & 27 & 14 \\
\hline
\end{tabular}

Source: Modified by the author from FAO (2000). 


\title{
Annex 3: Examples of the use of forest vocation land concept in forest laws of selected LA countries
}

\section{Country}

\author{
Definition and legal instrument
}

\begin{abstract}
Artículo 1.- Se considerarán terrenos de aptitud preferentemente forestal todos aquellos terrenos que por las
condiciones de clima y suelo no deban ararse en forma permanente, estén cubiertos o no de vegetación, excluyendo los que sin sufrir degradación puedan ser utilizados en agricultura, fruticultura o ganadería intensiva.

Ley de Bosques. Decreto $N^{\circ}$ 4.363.- 1931.
\end{abstract}

\begin{abstract}
Artículo 9.- ...b. Las tierras de vocación forestal, entendiéndose por tales los terrenos cubiertos o no de vegetación, que deben dedicarse a uso forestal exclusivo o preponderante por ser impropios para el cultivo agrícola, por su aptitud para la producción de maderas u otros productos forestales, por sus funciones o posibilidades protectoras sobre las aguas y suelo, por sus valores estéticos y recreativos o por cualquier otra razón de análogo interés general. ... Los márgenes fluviales y lacustres se consideran áreas forestales en la forma prevista en la presente Ley.

Ley Forestal de Honduras, 1971.
\end{abstract}

Articulo 7. XLI. Terreno preferentemente forestal: Aquel que habiendo estado, en la actualidad no se encuentra
cubierto por vegetación forestal, pero por sus condiciones de clima, suelo y topografía resulte más apto para el uso
forestal que para otros usos alternativos, excluyendo aquéllos ya urbanizados;
Ley General de Desarrollo Forestal Sustentable, 2003.

Art. $1^{\circ}$ As florestas existentes no território nacional e as demais formas de vegetação, reconhecidas de utilidade às terras que revestem, são bens de interesse comum a todos os habitantes do País, exercendo-se os direitos de propriedade, com as limitações que a legislação em geral e especialmente esta Lei estabelecem.

ำ

$\S 2^{\underline{0}}$ Para os efeitos deste Código, entende-se por:

II - área de preservação permanente: área protegida nos termos dos arts. $2^{\circ}$ e $3^{0}$ desta Lei, coberta ou não por vegetação nativa, com a função ambiental de preservar os recursos hídricos, a paisagem, a estabilidade geológica, a biodiversidade, o fluxo gênico de fauna e flora, proteger o solo e assegurar o bem-estar das populações humanas;

Nuevo Código Forestal. Ley No 4.771, 1965

Artículo 5.- 6. TIERRA DE VOCACION FORESTAL (Uso potencial): Tierra que por sus características climáticas, edáficas y topográficas debe ser utilizada para fines forestales.

Reglamento Forestal. 1993. 


\section{Annex 4: Forest vocation land estimation for selected Latin America and the Caribbean countries (1,000 ha)}

\begin{tabular}{|c|c|c|c|c|c|c|c|}
\hline & COUNTRIES & Total land & Pot. eq. arable & Desert areas & Arid areas & FVL $P$ & ential \\
\hline & (i) & $\left(V_{i}\right)$ & lands $\left(\mathrm{V}_{\mathrm{ii}}\right)$ & $\left(V_{\text {iii }}\right)$ & $\left(\mathrm{V}_{\mathrm{iv}}\right)$ & $\left(I_{i}\right)$ & $(\%)\left(I_{i i}\right)$ \\
\hline 1 & Brazil & 853,637 & 393,802 & 4,300 & 65,500 & 390,035 & 46 \\
\hline 2 & México (-) & 196,062 & 36,471 & 65,700 & 94,100 & 11,163 & $58(-)$ \\
\hline 3 & Colombia & 113,184 & 47,690 & 0 & 2,400 & 63,094 & 56 \\
\hline 4 & Peru & 128,922 & 30,567 & 18,800 & 25,200 & 54,355 & 42 \\
\hline 5 & Venezuela & 92,388 & 38,411 & 500 & 4,700 & 48,777 & 53 \\
\hline 6 & Argentina & 277,685 & 71,161 & 55,000 & 117,500 & 34,024 & 12 \\
\hline 7 & Chile & 75,202 & 2,003 & 23,100 & 17,800 & 32,299 & 43 \\
\hline 8 & Bolivia & 108,903 & 46,067 & 10,800 & 24,900 & 27,136 & 25 \\
\hline 9 & Paraguay & 39,905 & $1, .257$ & 0 & 6,100 & 20,548 & 51 \\
\hline 10 & Guyana & 20,907 & 9,739 & 100 & 0 & 11,068 & 53 \\
\hline 11 & Ecuador & 25,263 & 9,194 & 600 & 6,000 & 9,469 & 37 \\
\hline 12 & Honduras & 11,490 & 2,162 & 0 & 0 & 9,328 & 81 \\
\hline 13 & Nicaragua & 12,909 & 3,663 & 0 & 0 & 9,246 & 72 \\
\hline 14 & Bahamas (-) & 13,940 & nd & nd & nd & 8,046 & $58(-)$ \\
\hline 15 & Surinam & 14,429 & 6,736 & 0 & 0 & 7,693 & 53 \\
\hline 16 & Panama & 7,569 & 1,584 & 0 & 0 & 5,985 & 79 \\
\hline 17 & Uruguay & 17,907 & 12,522 & 0 & 0 & 5,385 & 30 \\
\hline 18 & Costa Rica & 5,200 & 858 & 0 & 0 & 4,342 & 84 \\
\hline 19 & Dominican Rep. & 4,879 & 1,418 & 0 & 0 & 3,461 & 71 \\
\hline 20 & El Salvador & 2,015 & 573 & 0 & 0 & 1,442 & 72 \\
\hline 21 & Belize & 2,063 & 709 & 0 & 0 & 1,354 & 66 \\
\hline 22 & Jamaica & 1,132 & 108 & 0 & 0 & 1,024 & 90 \\
\hline 23 & Guatemala & 11,045 & 2,821 & 0 & 0 & 8,224 & 74 \\
\hline 24 & Trinidad y Tobago & 514 & 226 & 0 & 0 & 288 & 56 \\
\hline 25 & Barbados (-) & 431 & nd & nd & nd & 249 & $58(-)$ \\
\hline 26 & Haiti & 2,723 & 511 & 0 & 0 & 2.212 & 81 \\
\hline
\end{tabular}

(-) Average data

(e) Estimated data;

$$
\mathrm{I}_{\mathrm{i}}=\mathrm{V}_{\mathrm{i}}-\mathrm{V}_{\mathrm{ii}}-\mathrm{V}_{\mathrm{iii}}-\mathrm{V}_{\mathrm{iv}}
$$$$
\mathrm{I}_{\mathrm{ii}}=\mathrm{I}_{\mathrm{i}} * 100 / \mathrm{V}_{\mathrm{i}}
$$

Source: FAO (2000); as prepared by STCP (2005) and modified by the author. 


\section{Annex 5: Glossary}

Agriculture use

Agriculture vocation land (AVL)

Agro-Ecological Zoning (AEZ),

Bad deforestation

Biological diversity

Biological resources

Buffer zone

Ecological-Economic

Zoning (EEZ)

Economic rent

Edge effect

Ex-situ conservation

Externalities

Any use of land that involve the production of non arbustive plants, cattle and other animal production.

Agriculture Vocation Lands are those that, due to their physical site features such as soil, topography, and the rainfall it receives, do not require exceptional protective measures to avoid soil and water related negative externalities. AVL classification does not depend on the type of cover the land actually has, nor does it depend on the requirements it may have for agriculture crop or forest production. Therefore, lands with forest cover or use can still be classified as AVL if their physical features so indicate; while lands not covered with forest may not be AVL.

a complex methodology that seeks to enable rational land-use planning, management and monitoring on the basis of an inventory of land resources, and an evaluation of biophysical limitations and potentials for specific crop production and crop production requirements. It tries to divide land into units with similar crop suitability, productivity potential and environmental impact.

means that either land rent is not being maximized or that soil and water externalities are affecting adversely society, or both.

means the variability among living organisms from all sources including, inter alia, terrestrial, marine and other aquatic ecosystems and the ecological complexes of which they are part; this includes diversity within species, between species and of ecosystems.*

includes genetic resources, organisms or parts thereof, populations, or any other biotic component of ecosystems with actual or potential use or value for humanity. *

“... an area that surrounds a wildland management area and serves to mitigate adverse effects from human activities outside the area." Ledec and Goodland, 1988

a kind of zoning which integrates in zone definitions Agro-ecological zoning elements with socio-economic factors and a wider range of land uses. Besides taking into account all the physical-biotic environment factors used in the AEZ methodology, it also considerers the socio-economic conditions affecting decision making.

is the proportion of the earnings of a factor of production that exceeds the minimum amount necessary to induce that factor to be supplied. William Blinder and Baumol, 2005: 404

Edge effects result from the exposure to very different ecological conditions that species have to face at the edges or perimeter of fragmented areas. While some species may prosper in those areas, there is important evidence that suggest that many species do not survive these changes, resulting in important modification of species composition (Lawrence, 1999). Besides, the edges tend to expand the deteriorated area further reducing the size of the remaining forest fragments, which seems to indicate a vicious circle that can lead to its drastic reduction in size. means the conservation of components of biological diversity outside their natural habitats. *

changes in a third party's welfare that result from decisions taken by someone who does not take in consideration such changes. When these decisions result in increase of the third party's welfare, it is said that a positive externality or external benefit have been generated. When these decisions result in decrease of the third party's welfare, it is said that a negative externality or external cost have been generated

\section{Forest cover}

An area ... more than 0.5 hectares with trees higher than 5 meters and a canopy cover of more than 10 percent, or trees able to reach these thresholds in situ. (FAO, 2004)

Forest land

Forest policies

Forest policies of the first group The set of FVL with and without forest cover plus AVL with forest cover.

Policies that seek to increase the contribution of forest lands to social welfare.

Policies that are designed to increase the contribution of the sector to social welfare through the sustainable provision of private goods and services. These policies are concerned with the competitiveness of the production agents, increasing productivity, and improving the supra, inter and intra sectorial business climate wherein forest related entrepreneurs can operate and prosper, etc. They seek to grow and develop forest related businesses.

Forest policies of the second group Policies concerned with the adequate provision of services for which no price is available, and therefore, the decisions of individual forest landowners do not take them into account in their decision making process. These services tend to be produced in smaller quantities than socially desirable or not at all. In addition, when misused, forest lands in fact may decrease social welfare, by the production of negative externalities. This second group of policies seeks to reduce negative externalities and produce adequate levels of the services (positive externalities 


Forest use
Forest vocation land
FVL)
Fragmentation

Genetic resources Good deforestation

In-situ conservation

Land cover

Land rent

Land use

Non-forest vocation

lands (nFVL)

Opportunity cost

Polluter-Pay Principle

Soil or water related externalities

\section{Sustainable agriculture}

Sustainable land use

or public goods) that societies require.

Any land use that involves a forest cover. It includes, for example, exotic or native species plantation forests, natural primary or secondary forests under management; agroforestry uses, arbustive fruit plantations, forest roads, firebreaks, recently harvested forests temporarily without forest cover and that will return to forest use, etc.

Forest Vocation Lands are those that, due to their physical site features such as soil, topography, and the rainfall it receives, should be kept under forest cover or other sustainable land use if soil or water related negative externalities are to be avoided. FVL classification does not depend on the type of cover the land actually has, nor does it depend on the requirements it may have for agriculture crop or forest production. Therefore, lands with no forest cover or use can still be classified as FVL if their physical features so indicate; while lands covered with forest may not be FVL.

the division of ecosystems in increasingly smaller and separate fragments with a total increase of perimeters and a reduction of continuous areas. The process increases the areas under the edge effect and reduces species diversity. means genetic material of actual or potential value.*

refers to the maximization of land rent at same time that soil and water negative externalities are not present.

... means the conservation of ecosystems and natural habitats and the maintenance and recovery of viable populations of species in their natural surroundings and, in the case of domesticated or cultivated species, in the surroundings where they have developed their distinctive properties.* the observed (bio) physical cover on the earth's surface, regardless of its use by people.

Rent on any piece of land will equal the difference between the cost of production the output on that land and the cost of production it on marginal land. William Blinder and Baumol, 2005: 405.

Refers to arrangements, activities and inputs people undertake in a certain land cover type to produce, change or maintain it.

Agriculture vocation lands plus all other land surfaces such as urban areas, water bodies. Excludes forest vocation lands.

The opportunity cost of any decision is the value of the next best alternative that the decision forces the decision maker to forgo. Blinder and Baumol, 2005: 39

The principle that those causing pollution should pay the costs of the measures to prevent, mitigate, correct or compensate for the environmental negative impacts that it may create for society.

Externalities associated with the use of the soil and which are the result of erosive and water runoff processes. These externalities affect on-site soil plant nutrition and water availability for plant consumption, generate loss of soil particles that will be deposited as siltation elsewhere in the landscape, affect water percolation into the soil, the quality, quantity, and time availability of water on water bodies, and affect water availability in ground water and springs. The phrase excludes pollution resulting from agrochemical use.

Agricultural production activities that do not generate soil or water related negative externalities.

Land use of any type that does not generate soil or water related negative externalities. It can be a sustainable agriculture use, a road, a building, forest cover, forest use.

*Convention on Biological Diversity, Article 2. 


Banco Interamericano de Desarrollo Departmento de Desarrollo Sostenible 1300 New York Ave., N.W., Washington, DC 20577, USA 